\title{
İnternet Alışverişlerinde Algılanan E-Hizmet Kalitesi, Müşteri Tatmini ve Müşteri Sadakati İlişkisinin İncelenmesi: Adıyaman Üniversitesi Öğrencileri Üzerine Bir Uygulama ${ }^{{ }^{*}}$
}

\author{
Arif YILDIZ \\ Dr. Öğr. Üyesi,Adıyaman Üniversitesi, \\ Gölbaşı Meslek Yüksekokulu, Yönetim ve Organizasyon Bölümü \\ arifyildiz@adiyaman.edu.tr \\ Orcid ID: https://orcid.org/0000-0002-5149-0447
}

\section{Şeyda KUYUCU}

Bilim Uzman1, seydaatnc@gmail.com

Orcid ID: https://orcid.org/0000-0003-3175-4975

\begin{abstract}
$\ddot{\mathbf{O z}}$
Teknolojide yaşanan gelişmeler, bilginin çok hızlı bir şekilde yayılıyor olması ve rekabetin her geçen gün yoğunlaşması, internet kullanımında ciddi bir artış meydana getirmiştir. İnternet kullanımında yaşanan artışlar, tüketicilerin satın alma alışkanlıklarında da birtakım değiş̧ikliklere sebep olmuştur. Bu çalışmanın amacı; internet alışverişlerinde tüketicilerin algıladıkları e-hizmet kalitesi ile müşteri tatmini ve müşteri sadakati arasındaki ilişkinin belirlenmesidir. Gerekli anket çalışmalarının yapılabilmesi amacıyla Adıyaman Üniversitesi, Sosyal ve Beşeri Bilimler Etik Kurulu'nun 26.04.2021 tarih-100 Nolu yazısı ile gerekli Etik Kurul izinleri alınmıştır. Bu kapsamda 2020-2021 Eğitim Öğretim döneminde Adıyaman Üniversitesi'nde öğrenim gören 453 öğrenciye çevrimiçi anket uygulanmıştır. Ankete katılan öğrencilerden 55'inin internetten alışveriş yapmadığı görülmüş, kalan 398 geçerli anket, analize tabi tutulmuştur. Yapılan analizler neticesinde; internet alışverişlerinde algılanan e-hizmet kalitesinin tüm alt boyutları ile müşteri tatmini arasında; algılanan e-hizmet kalitesinin tüm alt
\end{abstract}

\footnotetext{
${ }^{1}$ Makale Geliş/Kabul Tarihi: 30.08.2021 / 12.11.2021

* Bu çalışma; Adıyaman Üniversitesi, Lisansüstü Eğitim Enstitüsü, İşletme Ana Bilim Dalı'nda, Dr. Öğr. Üyesi Arif YILDIZ danışmanlığında, Şeyda KUYUCU tarafından tamamlanmış olan yüksek lisans tezinden üretilmiştir.

Künye Bilgisi: Yıldız, A. ve Kuyucu, Ş. (2021). İnternet alışverişlerinde algılanan ehizmet kalitesi, müşteri tatmini ve müşteri sadakati ilişkisinin incelenmesi: Adiyaman Üniversitesi öğrencileri üzerine bir uygulama. Kahramanmaraş Sütçü İmam Üniversitesi Sosyal Bilimler Dergisi, 18 (3), 2308-2343. DOI: 10.33437/ksusbd.988790
} 
boyutları ile müşteri sadakati arasında ve müşteri tatmini ile müşteri sadakati arasında istatiksel olarak pozitif yönde anlamlı ilişkiler tespit edilmiştir.

Anahtar Kelimeler: İnternetten Alışveriş, e-Ticaret, Algılanan Kalite, Müşteri Tatmini, Müşteri Sadakati.

\title{
Examining the Relationship of E-Service Quality, Customer Satisfaction and Customer Loyalty Perceived in Internet Shopping: An Application on Adıyaman University Students
}

\begin{abstract}
The developments in technology, the rapid spread of information and the intensification of competition day by day have created a serious increase in the use of the internet. The increase in internet usage has also caused some changes in the purchasing habits of consumers. The aim of this study; The aim of this study is to determine the relationship between the e-service quality perceived by consumers in internet shopping and customer satisfaction and customer loyalty. In order to carry out the necessary survey studies, the necessary Ethics Committee permissions were obtained with the letter No.-100 dated 26.04.2021 from the Social and Human Sciences Ethics Committee of Adiyaman University. In this context, an online questionnaire was applied to 453 students studying at Adiyaman University in the 2020-2021 academic year. It was observed that 55 of the students participating in the survey did not shop online, and the remaining 398 valid questionnaires were analyzed. As a result of the analyzes made; between all sub-dimensions of perceived e-service quality in internet shopping and customer satisfaction; Statistically positive and significant relationships were found between all sub-dimensions of perceived e-service quality and customer loyalty, and between customer satisfaction and customer loyalty.
\end{abstract}

Keywords: Online Shopping, e-Commerce, Perceived Quality, Customer Satisfaction, Customer Loyalty.

\section{GíRiş}

Teknolojik ilerlemeler, artan rekabet ve bilginin yayılma hızındaki artış gibi durumlar, internet kullanımını her alanda zorunlu hale getirmiştir. Günlük hayattaki değişimler, yeni iş alanları ve çalışma koşulları, trafikteki yoğunluklar, iş hayatında kadınların daha fazla yer almaya başlaması gibi durumlar; zamanın daha değerli olmasına sebep olmakta ve insanları daha fazla internetten alışveriş yapmaya zorlamaktadır. İnternet alışverişi, zamandan tasarrufa ilave olarak enerji ve para tasarrufu da sağlamaktadır. 
İnternet alışverişinin gelişmesi, işletmeler arasındaki rekabeti de arttırmış, işletmeler müşteri sadakatine daha çok önem vermeye başlamıştır. İnternet alışverişlerinde, geleneksel pazarlama anlayışında olduğu gibi kalite ve müşteri sadakatinin göz ardı edilmemesi gerekmektedir. Tüm bunların yanında hizmet kavramı önem kazanmış, hizmet işletmelerinin yanında mal üreten işletmeler de hizmet içerikli faaliyetlerde bulunmaya başlamıştır.

İnternetten alışverişin her geçen gün yaygınlaşması, internetten alışveriş imkanı sunan işletmeler arasında da bir rekabet ortamı oluşturmuştur. İşletmelerin rekabet avantajı sağlayabilmesi, bir yandan yeni müşteriler elde ederken diğer yandan da mevcut müşterilerini elde tutmaları ile mümkün olacaktır. Bir müşterinin, iletişim halinde olduğu işletmeden memnun olması müşteri sadakatini de beraberinde getirecektir.

$\mathrm{Bu}$ araştırmada; Adıyaman Üniversitesi öğrencilerinin alışverişleri sırasında algıladıkları e-hizmet kalitesi ile müşteri tatmini ve müşteri sadakati düzeyleri arasındaki ilişkinin ölçülmesi amaçlanmaktadır.

\section{KAVRAMSAL ÇERÇEVE}

$\mathrm{Bu}$ başlık altında İnternet alışverişi, algılanan e-hizmet kalitesi, müşteri tatmini ve son olarak müşteri sadakati kavramlarına yer verilmiştir.

\section{İnternet Alışverişi}

İnternetin yapısının açık olması ve düşük maliyeti, mevcut ve yeni bilgi ile iletişim teknolojilerini beraberinde getirmekte, işletmelere ve tüketicilere yenilikçi ve güçlü bir bilgi sistemi sunmaktadır. İnternet, alıcıların ve satıcıların bir araya gelmesini sağlamakta ve ekonomik süreçlerin yeniden örgütlenmesi için daha verimli bir şekilde yeni pazar yerleri ve firsatları yaratmaktadır. Aynı zamanda ürün yollarını, işletmeler ve tüketicilerin arama yöntemleri ve ürüne ulaşması için özelleştirmektedir (OECD, 2000).

İnternetin sürekli gelişim halinde olması ve gün geçtikçe internet kullanıcı sayısındaki artışlar, pazarlama alanındaki yeniliklere katkı sağlamıştır (Ünal, 2010: 157). Hızlı tüketim anlayışının ortaya çıkması ve kaliteli bir ürünü daha ucuza satın alma niyeti, internet alışverişini ve elektronik ticareti beraberinde getirmiştir (Bilgilier, 2019: 491).

Günümüz sanal pazar alanı olarak değerlendirilen internet, tüketicilere olduğu yerden hiçbir zahmete ve mağaza gezintilerine katlanmadan yeni bir alışveriş deneyimi sunmaktadır. İnternet ortamı sayesinde tüketiciler, gezip görülen fiziki ortamın tersine internet sitesinde rahat rahat gezip inceleme yapabildiği sanal ortama kavuşmuştur. Geleneksel mağazacılıkta ise böyle bir imkân 
bulunmamaktadır. $\mathrm{Bu}$ anlamda pazarlamanın tüketicilere sağlamış olduğu faydalardan biri olan mekân faydasının internet alışverişlerinde daha fazla ön plana çıktı̆g söylenebilir. Tüketiciler kendilerine sunulan ürünün kişiselleştirilebilmesi sayesinde daha hılı gezinti ve alışveriş yapabilmektedir (Enginkaya, 2006: 10).

Geleneksel pazarlama döneminde mal ve hizmet çeşitliliğinin yetersiz olması ülke ekonomilerinin dışarıya açılmasının önünde bir engel olmuştur. İnternetten alışverişin yaygınlaşması ile birlikte mal ve hizmet çeşitliliğinin artması rekabetin artmasına neden olmuş, böylece geleneksel pazarlamadaki pazar alanları yetersiz kalmaya başlamıştır (İçli, 2002: 3).

İnternetten alışverişin, internet kullanımı yoluyla tüketicilerin ulaştıkları ürün veya hizmeti satın almasına yönelik bir süreç olduğu söylenebilir (Gümül, 2015: 57). İnternetten alışveriş, internet aracılığıyla üyelik veya misafir olarak istenilen ürünün sanal veya kapıda ödeme yöntemiyle satın alınmasıdır (Wikipedia.org, 2019). Tüketicilerin internet üzerinden alışverişi benimsemeleri ve uygulamaları üzerindeki itici faktörler üç farklı şekilde sıralanabilir. Bunlardan ilki tüketicilerin kariyer planlamalarıyla birlikte iş hayatında geçen sürenin artması ve bunun sonucunda alışveriş için ayrılan sürenin kısalması; ikincisi, tüketicilerin zamanlarını sevdikleriyle geçirme talepleri; üçüncüsü ise tüketicilerin interneti eğlenebildikleri bir alan olarak görmesidir (Modahl, 2001: 146). Tüm bunların yanında ulaşım ve park sorunlarının yaşanması, alışveriş merkezlerinin konumları gibi sebepler de tüketicileri internetten alışveriş yapmaya yöneltmektedir (Kırcova, 2005: 68).

\section{Kalite ve Algılanan Kalite Kavramları}

Kalite kavramının kökeni, Eski Fransız "niteliği-la nuture" ve "nitelikleriqualies" kelimelerine dayanmaktadır. Bir nesnenin doğasını belirlemek için "ne tür" anlamına geldiği ve 13. Yüzyıla dayandığı bilinmektedir. Bu nedenle kalite kavramı, bir özellik, özerklik veya bir şeyin özelliği olarak tanımlanabilir. İş hayatında ise kalite kavramının ilk olarak, loncaların olduğu Orta Çağ Avrupa'sında kullanıldığı bilinmektedir. Lonca, kaliteli üretim için izlenmesi gereken zanaatkârlar birliğidir. Ürünler bu birlik tarafından kontrol edilerek piyasaya çıkmakta, piyasaya çıkmaya uygun görülmezse kaldırılmakta veya imha edilmektedir (Campanella, 1999: 30).

Mal ve hizmet açısından kalite kavramı kişilerin kullanım amaçlarına göre farklı anlamlara gelmektedir. Bunun nedeni, mal ve hizmet kalitesinin çok boyutlu olmasidır (Tekin, 2012: 6). Kalite, gereksinimlere uygunluktur (Crosby, 1979: 7). Kalite, bir ürün ya da hizmetin, beklenen ya da olabilecek ihtiyaçları karşılayabilme derecesinin toplamıdır (Şale, 2001: 23). Kalite; mal veya hizmet 
hakkında müşterinin görüşlerinin göstergesi, müşterinin istek ve ihtiyaçlarının ne derece karşılandığını gösteren bir ölçüdür (Tekin, 2012: 7).

Algılan kalite, müşterilerin bekledikleri kaliteye göre ürün veya hizmetin performansının kıyaslanması olarak tanımlanabilir (Aaker and Jacobson, 1994: 191). Algılanan kalitenin değerle ilişkili olduğu ve tekrar satın alma kararında isteklendirme ve başkalarına duyurmaya yarar sağladığı söylenebilir (Grewal, Monro and Krishnan, 1998: 46). Algılanan kalite aslında markanın, tüketicilerin isteklerinin algilama düzeyinde giderilme derecesi ile belirlenmektedir. $\mathrm{Bu}$ istekler farklı düzeylerdedir. Örneğin, hizmet markaları kullanıcılarının hizmetin sağladığı faydalara, hizmetin güvenli olmasına, hizmet sağlayıcısının dakik ve yardımsever olmasına, iletişim kolaylığı gibi durumlara yönelik olabilir (Franzen, 2002).

Aaker (1994), algılanan kaliteyi markanın önemli bileşenlerinden biri olarak belirtmektedir ve tüketiciler kişilikleri, ihtiyaçları ve tercihleri ile de algılarını şekillendirmektedirler (Aaker and Jacobson, 1994: 196). Algilanan kalite, memnuniyet ve tutumdan ayrı anlam taşımaktadır. Bir ürün hakkında düşük beklentisi olan bir tüketici, yüksek kalite sağlayarak tatmin edilebilir (Erdil ve Uzun, 2010: 231). Algılanan kalite, pazar payını, fiyat ve kârlılığı etkilemekte ve şirketin finansal performansına ve rekabet gücüne doğrudan etki etmektedir (kobitek.com).

E-hizmet kalitesi; bir müşterinin internet sitesi aracılığıyla gerçekleştirmiş olduğu etkili alışverişi, satın alma ve dağıtım kolaylığı gibi etkileşimlerinin tamamını kapsayacak şekilde geniş bir biçimde tanımlanmıştır (Parasuraman, Zeithaml and Malhotra, 2005: 217). E-hizmet kalitesi; hizmeti sağlayan firmanın, hizmetin satın alınması ve satın alım sonrası oluşan hizmet çıktılarının tüketicinin beklentilerini ne derece karşıladığını yine tüketici değerlendirmeleri aracılığıyla belirlenmesi şeklinde tanımlanmaktadır (Grönroos, Heinonen, Isoniemi and Lindholm, 2000: 245).

Teknolojide yaşanan gelişmeler, elektronik ticaretin, karşılaştırmalı sistemin yanında müşterilerin de hizmet kalitesi konusunda bilgili hale gelmesini sağlamıştır. Bu nedenle e-ticaret, e-hizmet, e-hizmet kalitesi ve kalitenin ölçülmesi pazarlama faaliyetlerinde bulunanların ilgi alanına dahil olmuştur. İnternetin gelişmesi ile birlikte bilgi gerektiren hizmetler, bilgisayar aracılığıyla elektronik ortamdan sunulmaya başlanmış ve gerçekleşen bu olaya ise "e-hizmet" adı verilmiştir (Bozbay, Yaman ve Özkan, 2016: 20). Elektronik ortamda hizmet sunan işletmeler ve yöneticilerin, verdikleri hizmeti müşterilerinin nasıl algıladığını bilmek, neleri önemsediklerini anlamak, kendilerini geliştirmeleri açısından önemlidir. Günümüzde internet üzerinden kaliteli ve ucuza ürün satmak yeterli olmamakta, farklı müşterilerin farklı istek ve ihtiyaçlarını karşılayabilecek 


\section{A.Yıldız-S.Kuyucu Internet Alısverislerinde Algılanan E-Hizmet...}

ölçüde hizmet kalitesi sunmak gerekmektedir (İlter, 2009: 99). Hizmet kalitesi, müşterilerin hizmetten beklentisi ile gerçekleşen hizmetin kıyaslanmasıdır. Burada bahsedilen "müşteri", sunulan hizmeti kullanmak amacıyla ödeme yapan taraftır. "Hizmet", somut bir varlığı olmayan ana veya tanımlayıcı faaliyet olarak belirtilmekte ve "kalite" ise, rakibinden üstün olan mal ve hizmeti tüketen tarafin algıladığı soyut veya somut karşılığıdır (Çiftçi, 2006: 14). E-hizmet kalitesi aslında hizmet sunan web sitesinin; alışveriş ve dağıtım işlemini, ne kadar etkili ve kolay bir hale getirdiğidir (Kipman, 2013: 46). E-Hizmet kalitesi, sadece ticari işletmelere rekabet ortamı sağlamamakta, müşteriler için geliştirilen müşteri ilişkileri ve daha kısa süreli geri dönüşlerle birlikte ürün geliştirmeye katk1 sunmaktadır (Şenel, Şenel ve Gümüştekin, 2012: 87).

\section{Müşteri Tatmini}

Müşteri, sunulan mal veya hizmetin nihai tüketen tarafidır (Wikipedia.org, 2019). Mevcut mal veya hizmet için ödeme yapan taraftır (TDK, 2019). Satın alma sürecinde duygusal ve bilişsel faktörlerin, satın alma ve satın alma sonrası değerlendirmeleri ve müssteri tatminine etkisi müşteriyi satın almaya yönlendirdiği söylenebilir (Özer, 1999: 161). Müşteriler, bilançoda yer almasa da işletmenin sahip olduğu en değerli varlıktır. Müşteri sadece ürün satın alan tarafi değil, işletmenin üretmiş olduğu mal ve hizmetlerin etkilediği herkesi kapsamaktadır (Tekin ve Zerenler, 2012: 267). Bilgi ve teknolojinin nesnel sonucu olarak tatmin kavramı önem kazanmıştır. İletişim ve ulaşım hızı, ikame ürünlerin keşfi, küreselleşme, ekonomik, hukuki, siyasi ve sosyo-kültürel gelişmelerle birlikte hiper rekabete bağlı meydana gelen "müşteri kraldır" ve "müşterimi memnun edersem satarım" düşüncesi oluşmaya başlamıştır. Bununla beraber işletmelerin teslim hızı, ürün kalitesi ve fiyat düzeyi gibi mükemmeliyetlerini ölçen araçlar da önem kazanmıştır (Naktiyok ve Küçük, 2003: 227).

Algilanan ve beklenen performansin yerine gelmesi durumunda, sunulan hizmet beklentiyi karşıliyorsa müşteri tatmin olmaktadır (Kotler, 2019: 90). Kısaca, müşterinin hizmetten beklentisi ve hizmeti aldıktan sonra oluşan algısının kıyaslanarak müşteri tatmin düzeyi ölçülebilmektedir (Türk, 2009: 404). Tatmin olan müşteriyi sadık müşteri haline getirebilmek için müşteriye daha kaliteli hizmetler, ürünler sunmak gerekmektedir. Müşterinin güven kazanması için istek ve ihtiyaçlarını tam karşılamak, sorunlarına çözüm bulmak işletmelerin önemli stratejileri haline gelmektedir (Demirkan, 2015: 10).

En genel tanımıyla müşteri tatmini, müşterinin satın alım sonrası elde ettiği çıktıdan kazandığı hoşnutluk duygusudur (Değermen, 2006: 26). 


\section{Müşteri Sadakati}

Türk Dil Kurumu (TDK) sadakat kavramını "içten gelen bağlılık, sağlam güçlü dostluk" olarak tanımlamaktadır (TDK, 2019). Müşteri sadakati; bir müşterinin elinde birçok tercih imkanı olmasına rağmen belirli mala veya hizmete ya da işletmeye karşı hissettiği yakınlık, bağlılık ve tesadüfi olmayan alışveriş tercihi, isteğidir (Bayuk ve Küçük, 2007: 290). Bir başka tanımda ise sadakat, "müşterilerin ürünü tekrar satın alarak satıcı perspektifinden gösterdiği olumlu tutumlar" şeklinde ifade edilmiştir (Çatı ve Koçoğlu, 2008: 169). Müşteri sadakatinden söz edebilmek için içten gelen bağlılık duygusunun olması, sadakat için zorunluluk veya kısıtlamanın olmaması ve müşterinin tercih edebileceği başka seçeneklerin bulunması gerekmektedir. Alternatif seçenek yoksa ve müşteri hep aynı yerden almaya mecbur kalıyorsa, sadakatten söz edilmeyecektir (Kirkbir, 2007: 62).

Müşteri sadakati kavramı, müşterinin bir marka veya işletmeye karşı duyduğu bağl1lık olarak tanımlanmaktadır (Oyman, 2002: 170). Bir diğer tanımda ise müşteri sadakati, tüm rekabetçi etkilere karşı müşterinin ne derece kararlı kaldığ 1 ve bağlı olduğu, işletme veya markanın ürün ve hizmetlerini kullanmaya devam ettiğidir (Baytekin, 2005: 49). Müşteri sadakati, bir müşterinin bir markay1 denemesi ve markaya karşı olumlu yönelimleri ve sürekliliğidir. Marka veya işletmeler varlıklarını devam ettirebilmek için kendisine yatırım yapanların, çalışanlarının ve alışveriş yapan tüm müşterilerinin sadakatini sağlamak durumundadır. Bir bakıma müşteri sadakati işletmenin müşterisi için değer yaratması ve karşıllğında müşterinin o işletmeyi benimsemesi şeklinde bütünlük kazanmaktadır (Çınar, 2007: 29-30). Memnun müşteriler yaratmak, müşterilerin daha sonraki satın alma kararlarında olumlu etkiye sahip olacağından site ziyaretlerini de arttıracağı düşünülmektedir (İlter, 2009: 103).

Davids'e göre başarılı işletmeler müşteri sadakatini oluşturmak için dört duruma yönelmektedir. Bunlar; "marka kişiselleştirmesi, çalışanların eğitilmesi, müşteri istek ve ihtiyaçlarına odaklanmak, istikrarlı ürün veya servis gelişimi sağlamak". İlave olarak müşteriler yalnız reklamlarla, fiyatlarla veya servis hizmetleriyle sadakat oluşturmazlar. Tüm bunlar için de ne istediğini bilen, hayatlarını daha iyi duruma getiren, onları önemseyen insanların olmasına da ihtiyaç duyabilmektedirler (Davids, 2007: 19).

Müşteri sadakatinin oluşabilmesi müşteri memnuniyetinden; müşteri memnuniyetinin oluşması ise, müşterinin mal veya hizmetten beklentilerinin tam ve doğru karşılanabilmesinden geçmektedir (İlter, 2009: 99). Müşteri sadakati, müşterinin bir ürün veya hizmetten memnun kalması ile oluşacağı gibi memnuniyetsizlik durumunda memnuniyetsizliğin en iyi şekilde giderilmesi ve 
müşteri kendisini değerli hissetmesi yoluyla da oluşabilecektir (Baytekin, 2005: 49).

\section{YÖNTEM}

$\mathrm{Bu}$ başlık altında; araştırmanın amacı, kapsamı, veri toplama araçları ve yöntemi, araştırmanın modeli ve hipotezleri konularına yer verilmiştir.

\section{Araştırmanın Amacı}

Bu araştırmada; Adıyaman Üniversitesi öğrencilerinin alışverişleri sırasında algıladıkları e-hizmet kalitesi ile müşteri tatmini ve müşteri sadakati düzeyleri arasındaki ilişkinin ölçülmesi amaçlanmaktadır. Bu temel amaca ilave olarak belirlenen alt amaçlar ise şöyledir:

- Katılımcıların demografik özelliklerini belirlemek,

- Katılımcıların, internette ne kadar vakit harcadıklarını ve ne sıklıkla internetten alışveriş yaptıklarını belirlemek,

- Öğrencilerin interneti hangi amaçla kullandıklarını, internetten alışveriş yapma sebeplerini ve alışveriş sitelerini kullanım sıklıklarını belirlemek,

- İnternet alışveriş sonucundaki algılanan e-hizmet kalitesi düzeyini (web sayfası verimliliği ve kullanılabilirliği, web sayfasının tasarımı, bilgi kalitesi, vaatleri yerine getirme, güvence, müşteri hizmetleri sipariş yönetimi) ölçmek,

- İnternetten alışveriş sonucundaki öğrencilerde oluşan müşteri tatminini ölçmek,

İnternetten alışveriş sonucundaki öğrencilerin müşteri sadakati düzeylerini belirlemek.

\section{Araştırmanın Kapsamı (Evren ve Örneklem)}

Araştırmada internet alışverişlerinde algılanan e-hizmet kalitesi, müşteri tatmini ve müşteri sadakati ilişkisinin incelenmesi amaçlanmıştır. Gerekli anket çalışmalarının yapılabilmesi amacıyla Adıyaman Üniversitesi, Sosyal ve Beşeri Bilimler Etik Kurulu'nun 26.04.2021 tarih-100 Nolu yazısı ile gerekli Etik Kurul izinleri alınmıştır. Çalışmanın evrenini 2020-2021 öğretim döneminde Adıyaman Üniversitesi'nde öğrenim gören 21.456 öğrenci oluşturmaktadır. Veriler, Nisan 2021-Haziran 2021 tarihleri arasında toplanmıştır. Araştırma kapsamında toplam 453 öğrenciye anket uygulanmış ancak bu öğrencilerin 55'inin internetten alışveriş yapmadıkları tespit edilmiştir. Geriye kalan toplam 398 katılımcı, araştırmanın örneklemini oluşturmaktadır. 


\section{Veri Toplama Araçları ve Yöntemi}

Bu araştırmada, algilana e-hizmet kalitesi, müşteri tatmini ve müşteri sadakati arasındaki ilişkiyi analiz etmek için oluşturulan bir on-line anket formu kullanılmıştır. Hazırlanan ölçeğin uygulanabilmesi amacıyla Adıyaman Üniversitesi Sosyal ve Beşeri Bilimler Etik Kurulu'nun 26.04.2021 tarih- 100 sayılı toplantı kararı ile gerekli izinler alınmıştır. Sonrasında ankette kullanılacak olan ölçeğin geçerlilik ve güvenilirliğinin tespit edilmesi amacıyla öncelikle 60 kişilik bir katılımcı grubu üzerinde pilot çalışma yapılmıştır. Ardından yapılan analizler neticesinde bazı soru ve önermeler ölçek kapsamından çıkarılarak, ankete nihai hali verilmiştir. İnternet üzerinden alışveriş yapmış internet kullanıcılarının, internet üzerinden alışveriş ile ilgili deneyimlerini, görüşlerini ve eğilimlerini belirlemek amaciyla hazırlanan on-line anket, internet kullanan tüketicilere sınıf grupları ve ögrenci grupları aracılığıyla uygulanmıştır.

\section{Anket Tasarımı}

Çalışma kapsamında verilerin toplanması amacıyla "İnternet Alışverişlerinde Algılanan E-Hizmet Kalitesi, Müşteri Tatmini ve Müşteri Sadakati İlişkisinin İncelenmesi: Adıyaman Üniversitesi Öğrencilerinin Üzerine Bir Uygulama” isimli anket düzenlenmiştir.

Anket 5 bölümden oluşmaktadır:

Birinci bölüm; cinsiyet, yaş, kayıtlı olunan birim, sınıf seviyesi, ailenin aylık geliri gibi demografik özellikleri belirlemek üzere hazırlanan sorulardan oluşmaktadır. İkinci bölüm; internetten alışveriş sıklığı, internet üzerinden satın alınan ürünlere harcanan miktar, internette kalma süresi, interneti kullanma nedenleri, alışveriş sitelerinin kullanım sıklıkları, ürün kategorileri alışveriş sıklıkları, internetten alışveriş nedenleri gibi internet kullanımının yer aldığı soruları kapsamaktadır. Üçüncü bölüm; algılanan e-hizmet kalitesine ilişkin alt boyutların yer aldığı önermeleri kapsamaktadır. Bu alt boyutlar; web sayfasının verimliliği ve kullanılabilirliği, web sayfasının tasarımı, bilgi kalitesi, vaatleri yerine getirme, güvence, müşteri hizmetleri, sipariş yönetimi şeklinde sıralanmıştır. Bu amaçla 5'li likert ölçeği (1= Kesinlikle Katılmıyorum, 2=Katılmıyorum, 3=Kararsızım, 4=Kayılıyorum ve 5= Kesinlikle Katıliyorum) şeklinde 40 önerme hazırlanmış ve katılımcılardan verilen önermelere katılma derecelerini belirtmeleri istenmiştir. Dördüncü bölümde müşteri tatminini ölçmeye yönelik 5 önerme yer almaktadır. Beşinci ve son bölümde ise, müşteri sadakatini ölçmeye yönelik 6 önerme yer almaktadır.

Araştırmada kullanılan ölçeklerin ankete uyarlanmış hali Tablo 1'de görüldüğü gibidir. İlgili ölçeklerin kullanımına dair gerekli izinler yazar (lar)dan alınmıştır. 
Tablo1. Geçerlilik Analizi Sonucu Ankette Kullanılan Ölçekler

\begin{tabular}{|l|l|l|}
\hline \multirow{5}{*}{$\begin{array}{l}\text { Algılanan E- } \\
\text { Hizmet } \\
\text { Kalitesi }\end{array}$} & $\begin{array}{l}\text { Web Sayfasının } \\
\text { Verimliliği ve } \\
\text { Kullanılabilirliği }\end{array}$ & (Kipman M., 2013) \\
\cline { 2 - 3 } & Tasarım & $\begin{array}{l}\text { (Mohamed, Elias and Arridha, 2015), } \\
\text { (Bayram, 2015) }\end{array}$ \\
\cline { 2 - 3 } & Yerine Getirme & (Mohamed, Elias and Arridha, 2015) \\
\cline { 2 - 3 } & Güvence & $\begin{array}{l}\text { (Kipman M. E., 2013), (Cristobal, Flavian } \\
\text { and Guinaliu, 2007), (Mohamed, Elias and } \\
\text { Arridha, 2015) }\end{array}$ \\
\cline { 2 - 3 } & Müşteri Hizmetleri & $\begin{array}{l}\text { (Cristobal, Flavian and Guinaliu, 2007), } \\
\text { (Kipman M. E., 2013) }\end{array}$ \\
\cline { 2 - 3 } & Sipariş Yönetimi & $\begin{array}{l}\text { (Cristobal, Flavian and Guinaliu, 2007), } \\
\text { (Kipman M. E., 2013) }\end{array}$ \\
\cline { 2 - 3 } & (Bayram, 2015), (Kipman M. E., 2013) \\
\hline Müşteri Memnuniyeti & (Kipman M. E., 2013), (Bayram, 2015) \\
\hline \multicolumn{2}{|l|}{ Müşteri Sadakati } &
\end{tabular}

\section{Araştırmanın Modeli ve Hipotezleri}

Araştırma kapsamında; internetten alışveriş sırasında algılanan e-hizmet kalitesi ile müşteri tatmini ve müşteri sadakati arasındaki ilişki belirlenmeye çalış1lmıştır.

Araştırmanın amacı doğrultusunda cevap aranan sorulara yönelik geliştirilen hipotezleri de barındıran araştırma modeli Şekil 1'de verilmiştir.

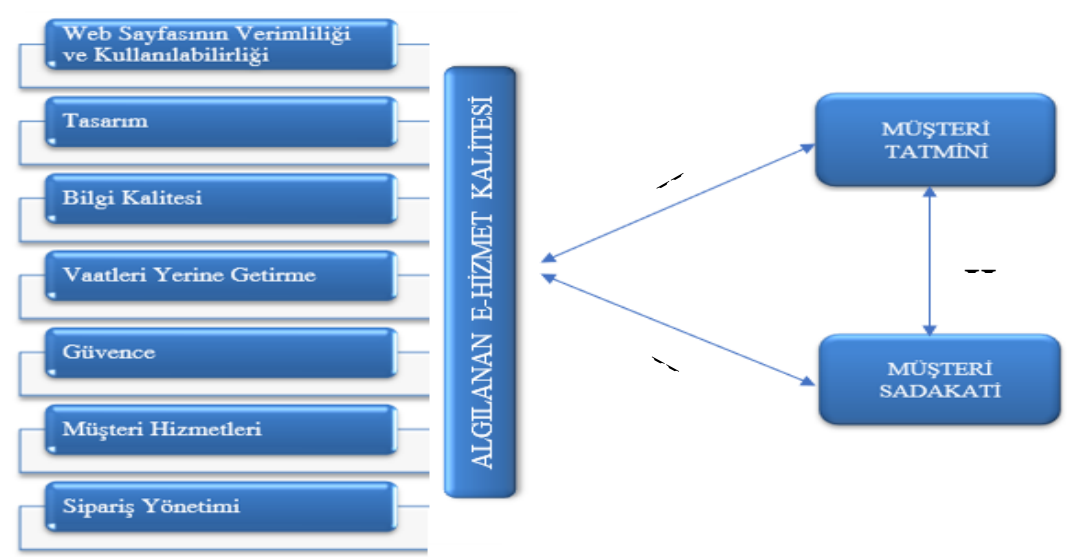

Şekil 1. Araştırma Modeli 
Araştırma modeli doğrultusunda araştırmanın soruları, hipotezler ve beklenen sonuçlara ilişkin bilgiler Tablo 2'de gösterilmiştir.

Tablo 2. Araştırma Soruları, Hipotezler ve Beklenen Sonuçlar

\begin{tabular}{|c|c|c|c|}
\hline $\begin{array}{l}\text { Sira } \\
\text { No }\end{array}$ & $\begin{array}{c}\text { Araştırmanın } \\
\text { Soruları }\end{array}$ & Hipotezler & Beklenen Sonuçlar \\
\hline 1 & $\begin{array}{l}\text { Adıyaman Üniversitesi } \\
\text { öğrencilerinin internet } \\
\text { alışverişlerinde } \\
\text { algıladıkları e-hizmet } \\
\text { kalitesi ve müşteri } \\
\text { tatmini arasında bir } \\
\text { ilişki var mıdır? }\end{array}$ & $\begin{array}{l}\mathrm{H}_{1} \text { : Adıyaman Üniversitesi } \\
\text { öğrencilerinin internet } \\
\text { alışverişlerinde } \\
\text { algıladıkları e-hizmet } \\
\text { kalitesi ile müşteri tatmini } \\
\text { arasında pozitif yönlü } \\
\text { anlamlı bir ilişki vardır. }\end{array}$ & $\begin{array}{l}\text { Adıyaman } \\
\text { Üniversitesi } \\
\text { öğrencilerinin internet } \\
\text { alışverişlerinde } \\
\text { algıladıkları e-hizmet } \\
\text { kalitesi ve müşteri } \\
\text { tatmini arasında } \\
\text { pozitif yönlü anlamlı } \\
\text { bir ilişki vardır. }\end{array}$ \\
\hline 2 & $\begin{array}{l}\text { Adıyaman Üniversitesi } \\
\text { öğrencilerinin internet } \\
\text { alışverişlerinde } \\
\text { algıladıkları e-hizmet } \\
\text { kalitesi ve müşteri } \\
\text { sadakati arasında bir } \\
\text { ilişki var mıdır? }\end{array}$ & $\begin{array}{l}\mathrm{H}_{2} \text { : Adıyaman Üniversitesi } \\
\text { öğrencilerinin internet } \\
\text { alışverişlerinde } \\
\text { alglladıkları e-hizmet } \\
\text { kalitesi ve müşteri sadakati } \\
\text { arasında pozitif yönlü } \\
\text { anlamlı bir ilişki vardır. }\end{array}$ & $\begin{array}{l}\text { Adıyaman } \\
\text { Üniversitesi } \\
\text { öğrencilerinin internet } \\
\text { alışverişlerinde } \\
\text { algıladıkları e-hizmet } \\
\text { kalitesi ve müşteri } \\
\text { sadakati arasında } \\
\text { pozitif yönlü anlamlı } \\
\text { bir ilişki vardır. }\end{array}$ \\
\hline 3 & $\begin{array}{l}\text { Adıyaman Üniversitesi } \\
\text { öğrencilerinin internet } \\
\text { alışverişlerinde müşteri } \\
\text { tatmini ile müşteri } \\
\text { sadakati arasında bir } \\
\text { ilişki var mıdır? }\end{array}$ & $\begin{array}{l}\mathrm{H}_{3} \text { : Adıyaman Üniversitesi } \\
\text { öğrencilerinin internet } \\
\text { alışverişlerinde müşteri } \\
\text { tatmini ile müşteri sadakati } \\
\text { arasında pozitif yönlü } \\
\text { anlamlı bir ilişki vardır. }\end{array}$ & $\begin{array}{l}\text { Adıyaman } \\
\text { Üniversitesi } \\
\text { öğrencilerinin internet } \\
\text { alışverişlerinde } \\
\text { müşteri tatmini ile } \\
\text { müşteri sadakati } \\
\text { arasında pozitif yönlü } \\
\text { anlamlı bir ilişki } \\
\text { vardır }\end{array}$ \\
\hline
\end{tabular}

Kaynak: Çelik, M. (2012: 39).

\section{BULGULAR}

Araştırma verilerinin analizi için IBM SPSS 20.0 paket programı kullanılmıştır. Araştırma bulguları ve analizinde, katılımcıların öncelikle demografik özelliklerine ilişkin frekans dağılımlarına yer verilmiştir. Ardından ölçeklerin güvenilirlik seviyesini belirlemek için Cronbach's Alpha değerinden ve geçerlilik testi için doğrulayıcı faktör analizinden, hipotezlerin ve değişkenlerin özellikleri için varyans analizi (ANOVA), T-testi ve korelasyon analizinden yararlanılmıştır. 


\section{A.Yıldız-S.Kuyucu İnternet Alısverislerinde Algılanan E-Hizmet...}

\section{Veri Setine İlişkin Faktör ve Güvenilirlik Analizleri}

Cronbach's Alpha değeri, faktör altındaki soruların toplamdaki güvenilirlik seviyesini göstermektedir. Bir ölçeğe güvenilirlik hesaplaması yapılabilmesi için en az 50 anket ve 30 maddeden oluşması gerekmektedir (Kalayc1, 2005: 403404).

Araştırmada kullanılan ölçeğe ilişkin Cronbach's Alpha değerlerine Tablo 3'te yer verilmiştir.

Tablo 3. Öıçeğe İlişkin Güvenilirlik Bulguları

\begin{tabular}{|c|c|}
\hline Cronbach's Alpha & N of Items \\
\hline, 980 & 51 \\
\hline
\end{tabular}

Cronbach's Alpha değerleri aşağıdaki gibi yorumlanmaktadır (Kalaycı, 2005: 405).

- $0,00-0,40$ ise ölçek güvenilir değildir.

- $0,40-0,60$ ise ölçeğin güvenirliği düşüktür.

- $0,60-0,80$ ise ölçek oldukça güvenilirdir.

- 0,80-1,00 ise ölçek yüksek derecede güvenilirdir.

Çalışmada Adıyaman Üniversitesi öğrencileri örneklemi için kullanılan ölçeğin Cronbach's Alpha değeri 0,980 olarak bulunmuştur. Bu oran yüksek derecede güvenilir aralığına denk gelmektedir.

Veri setinin faktör analizi için uygun olup olmadığını değerlendirmek için üç yöntem kullanılmaktadır. Bunlar; korelasyon matrisinin oluşturulması, Barlett's testi ve Kaiser-Mayer-Olkin (KMO) testleridir. KMO değerinin 0,50 'den büyük olması halinde veri setinin faktör analizine uygun olduğu şeklinde yorumlanmaktadır (Kalayc1, 2005: 321-322).

Örnek büyüklügünün faktör analizi için uygun olup olmadığının anlaşılması için yapılan analiz sonucunda $\mathrm{KMO}=0,950$ olarak hesaplanmış, Bartlett's testi de istatistiksel olarak anlamlı (Ki-Kare 22606,036 p=0,00) çıkmıştır. Bartlett's test sonucunun anlamlı çıkması, verilerin normal dağılım gösterdiği sonucunu vermektedir. Bu testlerin sonuçlarına göre verilerin faktör analizi için uygun olduğu anlaşılmıştır. KMO ve Bartlett's test sonucuna Tablo 4 'te yer verilmiştir. 
Tablo 4. KMO ve Bartlett's Testi Sonuçları

\begin{tabular}{lll}
\hline \multicolumn{2}{c}{$\begin{array}{c}\text { Kaiser-Meyer-Olkin Measure of Sampling } \\
\text { Adequacy }\end{array}$} & \multicolumn{1}{c}{, 950} \\
\hline & Approx. & 22606,036 \\
Bartlett's Test of Sphericity & Chi-Square & \\
& Df & 1275 \\
& Sig. &, 000 \\
\hline
\end{tabular}

\section{Demografik Değișkenlere İlișkin Bulgular}

Katılımcıların demografik özellikleri Tablo 5'te görüldüğü gibidir.

Tablo 5. Katılımcıların Demografik Özellikleri

\begin{tabular}{|c|c|c|c|}
\hline \multicolumn{2}{|c|}{ Demografik Özellikler } & $\mathbf{N}$ & Yüzde (\%) \\
\hline \multirow{3}{*}{ Cinsiyet } & Kadın & 229 & 57,5 \\
\hline & Erkek & 169 & 42,5 \\
\hline & TOPLAM & 398 & 100 \\
\hline \multirow{8}{*}{ Yaş } & 20 yaş ve aşağıs1 & 86 & 21,6 \\
\hline & $21-23$ yaş & 175 & 44,0 \\
\hline & $24-26$ yaş & 61 & 15,3 \\
\hline & $27-29$ yaş & 24 & 6,0 \\
\hline & $30-32$ yaş & 17 & 4,3 \\
\hline & $33-35$ yaş & 18 & 4,5 \\
\hline & 36 ve sonrası yaş & 17 & 4,3 \\
\hline & TOPLAM & 398 & 100 \\
\hline \multirow{4}{*}{ Eğitim Durumu } & Önlisans & 198 & 49,7 \\
\hline & Lisans & 179 & 45,0 \\
\hline & Lisansüstü Eğitim & 21 & 5,3 \\
\hline & TOPLAM & 398 & 100 \\
\hline \multirow{8}{*}{ Sinif } & Hazırlık & 3 & ,8 \\
\hline & 1.Sinif & 127 & 31,9 \\
\hline & 2.Sinıf & 133 & 33,4 \\
\hline & 3.Sinif & 77 & 19,3 \\
\hline & 4.Sinif & 51 & 12,8 \\
\hline & 5.Sinif & 2 &, 5 \\
\hline & 6.Sinif & 5 & 1,3 \\
\hline & TOPLAM & 398 & 100 \\
\hline \multirow{6}{*}{ Gelir Durumu } & Yok & 22 & 5,5 \\
\hline & Asgari & 146 & 36,7 \\
\hline & $3000-4500$ & 120 & 30,2 \\
\hline & $4501-6000$ & 43 & 10,8 \\
\hline & $6001-7500$ & 38 & 9,5 \\
\hline & 7501 ve fazlas 1 & 29 & 7,3 \\
\hline
\end{tabular}




\section{A.Yıldız-S.Kuyucu Internet Alısverislerinde Algılanan E-Hizmet...}

\begin{tabular}{llcc} 
& TOPLAM & $\mathbf{3 9 8}$ & $\mathbf{1 0 0}$ \\
\hline & Her gün & 2 &, 5 \\
2-3 günde bir & 4 & 1,0 \\
Alışveriş Sıklığ1 & Haftada bir & 53 & 13,3 \\
& Ayda bir & 113 & 28,4 \\
& Birkaç ayda bir & 226 & 56,8 \\
\cline { 2 - 3 } & TOPLAM & $\mathbf{3 9 8}$ & $\mathbf{1 0 0}$
\end{tabular}

Öğrencilerin demografik özelliklerini belirlemeye yönelik yapılan analiz sonuçlarına Tablo 5'te yer verilmiştir. Buna göre; katılımcıların 169'u $(\% 42,5)$ erkeklerden, 229'u (\%57,5) kadınlardan oluşmaktadır. Katılımcıların yaş aralığ 1 incelendiğinde; ağırlıklı olarak 21-23 yaş aralığında oldukları görülmektedir $(\% 44,0)$. Katılımcıların okudukları birim ve sınıfları incelendiğinde; 198 kişi $(\% 49,7)$ ile yoğunluğun önlisansta ve 133 kişi $(\% 33,4)$ ile yoğunluğun ikinci sınıfta olduğu görülmektedir. Ankete katılanların ailelerinin aylık gelir durumuna bakıldığında; en fazla yoğunluğun asgari gelir durumu düzeyinde olduğu tespit edilmiştir $(\% 36,7)$. Katılımcıların alışveriş yapma sıklığı sorulduğunda ise; 226 kişi $(\% 56,8)$ birkaç ayda bir alışveriş yaptığını belirtmiştir.

\section{İnternet Kullanımı ve İnternetten Alışveriş Durumlarına Yönelik Bulgular}

Katılımcıların; bir yıl içerisinde internet üzerinden satın aldıkları ürünlere ilişkin harcama tutarları, bir gün içerisinde internette kaldıkları süreler, interneti kullanma nedenleri, alışveriş sitelerini kullanım sıklıkları, ürün kategorilerine göre alışveriş sıklıkları ve internetten alışveriş nedenlerine Tablo 6'da yer verilmiş̧ir.

Tablo 6. Bir Yıl İçerisinde İnternet Üzerinden Satın Alınan Ürünlere Harcanan Tutar

\begin{tabular}{lcc}
\hline Harcanan Tutar & Frekans (F) & Yüzde (\%) \\
\hline 1000 TL ve aşağısı & 273 & 68,6 \\
1001 TL- 2000TL & 45 & 11,3 \\
2001 TL- 3000TL & 22 & 5,5 \\
3001 TL- 4000 TL & 28 & 7,0 \\
4001TL -5000TL & 4 & 1,0 \\
5001 ve yukarısı & 26 & 6,6 \\
Toplam & $\mathbf{3 9 8}$ & $\mathbf{1 0 0}$ \\
\hline
\end{tabular}

Tablo 6'da görüldüğü üzere; katılımc1ların büyük çoğunluğu $(\% 68,6)$ bir y1l içerisinde $1000 \mathrm{TL}$ ve aşağısı gibi düşük bir tutarda internetten alışveriş̧ yapmaktadır. Bu durum kendi kişisel gelirinin düşük olması ya da kişisel 
harcamalarının ailenin başka bireyleri tarafından yapılıyor olması şeklinde açıklanabilir.

Tablo 7. Bir gün İçerisinde İnternette Kalınan Süre

\begin{tabular}{lcc}
\hline Harcanan Süre & Frekans $(\mathbf{F})$ & Yüzde (\%) \\
\hline 2 saat ve aşağısı & 77 & 19,3 \\
3-4 saat & 118 & 29,6 \\
5-6 saat & 109 & 27,4 \\
7-8 saat & 48 & 12,1 \\
9-10 saat & 29 & 7,3 \\
10 saatten fazla & 17 & 4,3 \\
\hline Toplam & $\mathbf{3 9 8}$ & $\mathbf{1 0 0}$ \\
\hline
\end{tabular}

Tablo 7'de anket katılımcılarının bir günde internette harcadıkları süreye bakıldığında; \%29,6'sı 3-4 saat aralığında internette kalırken, \%4,3'ünün 10 saatten fazla kaldığ 1 görülmektedir.

Tablo 8. İnterneti Kullanma Nedenleri

\begin{tabular}{llcc}
\hline Interneti Kullanma Nedenleri & & Frekans (F) & Yüzde (\%) \\
\hline & Hiçbir zaman & 21 & 5,3 \\
& Nadiren & 104 & 26,1 \\
& Ara sira & 109 & 27,4 \\
Mailleri Kontrol Etmek & Sik sik & 113 & 28,4 \\
& Her zaman & 51 & 12,8 \\
\cline { 2 - 4 } & TOPLAM & $\mathbf{3 9 8}$ & $\mathbf{1 0 0}$ \\
\hline \multirow{5}{*}{ Haber Okumak-İzlemek } & Hiçbir zaman & 19 & 4,8 \\
& Nadiren & 69 & 17,3 \\
& Ara sira & 136 & 34,2 \\
& Sik sik & 127 & 31,9 \\
& Her zaman & 47 & 11,8 \\
\cline { 2 - 4 } Film İzlemek & TOPLAM & $\mathbf{3 9 8}$ & $\mathbf{1 0 0}$ \\
\hline & Hiçbir zaman & 32 & 8,0 \\
& Nadiren & 90 & 22,6 \\
& Ara sira & 134 & 33,7 \\
& Sik sik & 107 & 26,9 \\
& Her zaman & 35 & 8,8 \\
\cline { 2 - 4 } & TOPLAM & $\mathbf{3 9 8}$ & $\mathbf{1 0 0}$ \\
\hline & Hiçbir zaman & 18 & 4,5 \\
& Nadiren & 56 & 14,1 \\
& Ara sira & 77 & 19,3 \\
& Sik sik & 136 & 34,2
\end{tabular}


A.Yıldız-S.Kuyucu İnternet Alısverislerinde Algılanan E-Hizmet...

\begin{tabular}{|c|c|c|c|}
\hline & Her zaman & 111 & 27,9 \\
\hline & TOPLAM & 398 & 100 \\
\hline \multirow{6}{*}{ Sosyal Medyayı Takip Etmek } & Hiçbir zaman & 3 & ,8 \\
\hline & Nadiren & 30 & 7,5 \\
\hline & Ara sira & 80 & 20,1 \\
\hline & Sik s1k & 138 & 34,7 \\
\hline & Her zaman & 147 & 36,9 \\
\hline & TOPLAM & 398 & 100 \\
\hline \multirow{6}{*}{ Oyun Oynamak } & Hiçbir zaman & 156 & 39,2 \\
\hline & Nadiren & 81 & 20,4 \\
\hline & Ara sira & 73 & 18,3 \\
\hline & Sik sik & 56 & 14,1 \\
\hline & Her zaman & 32 & 8,0 \\
\hline & TOPLAM & 398 & 100 \\
\hline \multirow{6}{*}{ Bankacılık İşlemleri-Alışveriş } & Hiçbir zaman & 18 & 4,5 \\
\hline & Nadiren & 106 & 26,6 \\
\hline & Ara sira & 139 & 34,9 \\
\hline & Sik sik & 105 & 26,4 \\
\hline & Her zaman & 30 & 7,6 \\
\hline & TOPLAM & 398 & 100 \\
\hline \multirow{6}{*}{ Sadece Mesleki İşlerde Kullanmak } & Hiçbir zaman & 49 & 12,3 \\
\hline & Nadiren & 116 & 29,1 \\
\hline & Ara sira & 124 & 31,2 \\
\hline & Sik s1k & 85 & 21,4 \\
\hline & Her zaman & 24 & 6,0 \\
\hline & TOPLAM & 398 & 100 \\
\hline \multirow{6}{*}{ Şans Oyunları Oynamak } & Hiçbir zaman & 336 & 84,4 \\
\hline & Nadiren & 33 & 8,3 \\
\hline & Ara sira & 11 & 2,8 \\
\hline & Sik sik & 14 & 3,5 \\
\hline & Her zaman & 4 & 1,0 \\
\hline & TOPLAM & 398 & 100 \\
\hline \multirow{6}{*}{ İnternet Üzerinden Para Kazanmak } & Hiçbir zaman & 308 & 77,4 \\
\hline & Nadiren & 35 & 8,8 \\
\hline & Ara sira & 27 & 6,8 \\
\hline & Sik sik & 26 & 6,5 \\
\hline & Her zaman & 2 &, 5 \\
\hline & TOPLAM & 398 & 100 \\
\hline \multirow{6}{*}{ Araştırma Yapmak } & Hiçbir zaman & 3 & ,8 \\
\hline & Nadiren & 30 & 7,5 \\
\hline & Ara sira & 124 & 31,2 \\
\hline & Sik sik & 160 & 40,1 \\
\hline & Her zaman & 81 & 20,4 \\
\hline & TOPLAM & 398 & 100 \\
\hline \multirow{2}{*}{ Ödev Yapmak } & Hiçbir zaman & 12 & 3,0 \\
\hline & Nadiren & 51 & 12,8 \\
\hline
\end{tabular}




\begin{tabular}{|c|c|c|c|}
\hline & Ara sira & 126 & 31,7 \\
\hline & Sik sik & 141 & 35,4 \\
\hline & Her zaman & 68 & 17,1 \\
\hline & TOPLAM & 398 & 100 \\
\hline \multirow{6}{*}{ Yabancı Dil Geliştirmek } & Hiçbir zaman & 99 & 24,9 \\
\hline & Nadiren & 107 & 26,8 \\
\hline & Ara sira & 91 & 22,9 \\
\hline & Sik sik & 66 & 16,6 \\
\hline & Her zaman & 35 & 8,8 \\
\hline & TOPLAM & 398 & 100 \\
\hline \multirow{6}{*}{$\begin{array}{l}\text { Uzaktan (Online) Eğitime Devam } \\
\text { Etmek }\end{array}$} & Hiçbir zaman & 15 & 3,8 \\
\hline & Nadiren & 21 & 5,3 \\
\hline & Ara sira & 34 & 8,5 \\
\hline & Sik sik & 135 & 33,9 \\
\hline & Her zaman & 193 & 48,5 \\
\hline & TOPLAM & 398 & 100 \\
\hline \multirow{6}{*}{ Diğer (İş Aramak vb.) } & Hiçbir zaman & 116 & 29,2 \\
\hline & Nadiren & 110 & 27,6 \\
\hline & Ara sira & 74 & 18,6 \\
\hline & Sik s1k & 64 & 16,1 \\
\hline & Her zaman & 34 & 8,5 \\
\hline & TOPLAM & 398 & 100 \\
\hline
\end{tabular}

Tablo 8'de katılımcıların interneti kullanma nedenlerine bakıldığında; 113 kişi $(\% 28,4)$ sık sık e-postalarını kontrol etmek için kullandığını, 21 kişi ise $(\% 5,3)$ maillerini hiçbir zaman kontrol etmediğini belirtmiştir. Katılımcıların $(\% 34,2)$ 'si ara sıra haber okumak-izlemek için kullanırken, $(\% 4,8)$ 'i interneti haber okumak-izleme amacıyla hiçbir zaman kullanmamaktadır. Katılımcılardan 134 kişi ara sıra film izlemek için kullanırken, 32 kişinin ise hiçbir zaman film izlemediği görülmüştür. Yine 136 kişinin interneti sık sık müzik dinlemek için kullandığı ancak 18 kişinin hiç kullanmadığ 1 sonuçlarına ulaşılmıştır. Katılımcıların \%34,7'si sosyal medyayı internetten s1k s1k takip ederken \%,8'i ise hiç bu amaçla kullanmamıştır. 156 kişi hiçbir zaman interneti oyun oynamak için kullanmazken, 32 kişinin interneti her zaman oyun amaçlı kullandığına dair bulgular elde edilmiştir. Katılımcıların \%34,9'u internetti bankacılık işlemlerialışveriş için ara sıra kullanırken \%4,5'inin hiçbir zaman bankacılık işlemlerialışveriş için interneti kullanmadı görülmüştür. Katılımcıların \%31,2'si interneti sadece mesleki işlerde kullanmak için ara sıra kullanırken \%6'sı her zaman interneti mesleki işlerde kullanmaktadır. Katılımcıların \%84,4'ü internetti şans oyunları oynamak için hiçbir zaman kullanmazken \%1'i her zaman internet şans oyunları oynamak amacıyla kullanmaktadır. Katılımcılardan \%77,4'ü internet üzerinden para kazanmak için hiçbir zaman interneti kullanmıyorken \%,5'i her zaman internet üzerinden para kazanmak için interneti kullandığı görülmektedir. 


\section{A.Yıldız-S.Kuyucu Internet Alısverislerinde Algılanan E-Hizmet...}

Katılımcıların \%40,2'si interneti sık sık araştırma yapmak için kullanırken, \%8'i hiç araştırma yapmamaktadır. Katılımcıların \%35,4'ü interneti ödev yapmak için sık sık, \%3'ü ise interneti ödev yapmak için hiçbir zaman kullanmadığ 1 görülmektedir. Katılımcıların $\% 26,9$ 'u nadiren de olsa interneti yabancı dili geliştirmek amaçlı kullanırken, \%8,8'i her zaman yabancı dili geliştirmek için interneti kullanmaktadır. Kat1lımcılardan \%48,5'i interneti uzaktan (online) eğitime devam etmek için her zaman; \%3,8'i ise uzaktan (online) eğitime hiçbir zaman devam etmediğini belirtmiştir. Katılımcılardan \%8,5'i interneti diğer (iş aramak vb.) işlemlerde her zaman kullanırken, \%29,1'i interneti diğer (iş aramak vb.) işlemlerde hiçbir zaman kullanmamaktadır.

Tablo 9. Alışveriş Sitelerinin Kullanım Sıklıkları

\begin{tabular}{|c|c|c|c|}
\hline Alışveriş Sitelerinin Kullanım Sıklıkları & & Frekans (F) & Yüzde (\%) \\
\hline \multirow[t]{6}{*}{ 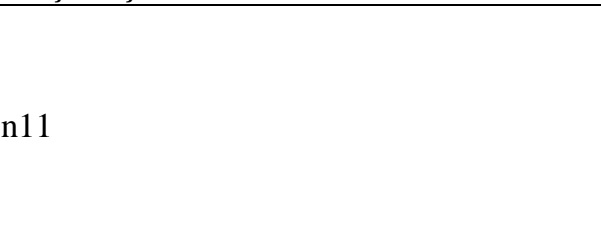 } & Hiçbir zaman & 226 & 56,8 \\
\hline & Nadiren & 92 & 23,1 \\
\hline & Ara sira & 57 & 14,3 \\
\hline & Sik sik & 12 & 3,0 \\
\hline & Her zaman & 11 & 2,8 \\
\hline & TOPLAM & 398 & 100 \\
\hline \multirow{6}{*}{ Hepsiburada } & Hiçbir zaman & 160 & 40,2 \\
\hline & Nadiren & 103 & 25,9 \\
\hline & Ara sira & 89 & 22,4 \\
\hline & Sik sık & 32 & 8,0 \\
\hline & Her zaman & 14 & 3,5 \\
\hline & TOPLAM & 398 & 100 \\
\hline \multirow{6}{*}{ GittiGidiyor } & Hiçbir zaman & 219 & 55,0 \\
\hline & Nadiren & 89 & 22,4 \\
\hline & Ara sira & 58 & 14,6 \\
\hline & Sik sık & 18 & 4,5 \\
\hline & Her zaman & 14 & 3,5 \\
\hline & TOPLAM & 398 & 100 \\
\hline \multirow{6}{*}{ Trendyol } & Hiçbir zaman & 30 & 7,5 \\
\hline & Nadiren & 60 & 15,1 \\
\hline & Ara sira & 78 & 19,6 \\
\hline & Sik sık & 101 & 25,4 \\
\hline & Her zaman & 129 & 32,4 \\
\hline & TOPLAM & 398 & 100 \\
\hline \multirow{6}{*}{ Çiçek Sepeti } & Hiçbir zaman & 144 & 36,3 \\
\hline & Nadiren & 100 & 25,1 \\
\hline & Ara sira & 96 & 24,1 \\
\hline & Sik sık & 34 & 8,5 \\
\hline & Her zaman & 24 & 6,0 \\
\hline & TOPLAM & 398 & 100 \\
\hline Letgo & Hiçbir zaman & 290 & 72,9 \\
\hline
\end{tabular}




\begin{tabular}{|c|c|c|c|}
\hline & Nadiren & 53 & 13,3 \\
\hline & Ara sira & 31 & 7,8 \\
\hline & Sik sik & 12 & 3,0 \\
\hline & Her zaman & 12 & 3,0 \\
\hline & TOPLAM & 398 & 100 \\
\hline \multirow{6}{*}{ Sosyal Medya (Instagram, Facebook vb.) } & Hiçbir zaman & 117 & 29,4 \\
\hline & Nadiren & 65 & 16,3 \\
\hline & Ara sira & 78 & 19,6 \\
\hline & Sik sık & 39 & 9,8 \\
\hline & Her zaman & 99 & 24,9 \\
\hline & TOPLAM & 398 & 100 \\
\hline \multirow{6}{*}{ PTT Avm } & Hiçbir zaman & 265 & 66,5 \\
\hline & Nadiren & 81 & 20,4 \\
\hline & Ara sira & 35 & 8,8 \\
\hline & Sik sik & 14 & 3,5 \\
\hline & Her zaman & 3 &, 8 \\
\hline & TOPLAM & 398 & 100 \\
\hline \multirow{6}{*}{ Dolap } & Hiçbir zaman & 298 & 74,8 \\
\hline & Nadiren & 45 & 11,3 \\
\hline & Ara sira & 27 & 6,8 \\
\hline & Sik sik & 23 & 5,8 \\
\hline & Her zaman & 5 & 1,3 \\
\hline & TOPLAM & 398 & 100 \\
\hline \multirow{6}{*}{ Sahibinden } & Hiçbir zaman & 257 & 64,5 \\
\hline & Nadiren & 52 & 13,1 \\
\hline & Ara sira & 48 & 12,1 \\
\hline & S1k s1k & 29 & 7,3 \\
\hline & Her zaman & 12 & 3,0 \\
\hline & TOPLAM & 398 & 100 \\
\hline \multirow{6}{*}{ AliExpres } & Hiçbir zaman & 307 & 77,1 \\
\hline & Nadiren & 55 & 13,8 \\
\hline & Ara sira & 23 & 5,8 \\
\hline & Sik sik & 10 & 2,5 \\
\hline & Her zaman & 3 &, 8 \\
\hline & TOPLAM & 398 & 100 \\
\hline \multirow{6}{*}{ Amazon } & Hiçbir zaman & 306 & 76,9 \\
\hline & Nadiren & 41 & 10,3 \\
\hline & Ara sira & 24 & 6,0 \\
\hline & Sik sık & 17 & 4,3 \\
\hline & Her zaman & 10 & 2,5 \\
\hline & TOPLAM & 398 & 100 \\
\hline \multirow{5}{*}{ Alibaba } & Hiçbir zaman & 338 & 84,8 \\
\hline & Nadiren & 35 & 8,8 \\
\hline & Ara sira & 11 & 2,8 \\
\hline & Sik sik & 11 & 2,8 \\
\hline & Her zaman & 3 & 8 \\
\hline
\end{tabular}




\begin{tabular}{lll}
\hline TOPLAM & 398 & 100
\end{tabular}

Tablo 9'da anket katılımcılarının alışveriş sitelerini ne sıklıkla kullandıklarına bakıldığında en fazla tercih edilen alışveriş sitesinin/uygulamasının Trendyol olduğu (ara sira + sık sık + her zaman=\%77,4) görülmektedir. En az tercih edileni ise \%93,7 (hiçbir zaman+ nadiren) oran ile Alibaba'dır. Öte yandan n11'i 226 kişi $(\% 56,8)$ hiçbir zaman, 11 kişi $(\% 2,8)$ her zaman; Hepsiburada'yı 160 kişi $(\% 40,2)$ hiçbir zaman, 14 kişi $(\% 3,5)$ her zaman; Gittigidiyor'u 219 kişi $(\% 55,0)$ hiçbir zaman, 14 kişi $(\% 3,5)$ her zaman; Çiçek Sepeti’ni 144 kişi $(\% 36,2)$ hiçbir zaman, 24 kişi $(\% 6,0)$ her zaman; Letgo'yu 290 kişi $(\% 72,9)$ hiçbir zaman 12 kişi $(\% 3,0)$ sık sık ve her zaman; sosyal medya (Instagram, Facebook vb.), 117 kişi $(\% 29,4)$ hiçbir zaman, 39 kişi $(\% 9,8)$ sık sık; PTT Avm'yi 265 kişi $(\% 66,6)$ hiçbir zaman, 3 kişi $(\%, 8)$ her zaman; Dolap uygulamasını 298 kişi $(\% 74,9)$ hiçbir zaman, 5 kişi $(\% 1,3)$ her zaman; Sahibinden'i 257 kişi $(\% 64,6)$ hiçbir zaman, 12 kişi $(\% 3,0)$ her zaman; AliExpres'i 307 kişi $(\% 77,1)$ hiçbir zaman, 3 kişi $(\%, 8)$ her zaman; Amazon'u 306 kişi $(\% 76,9)$ hiçbir zaman, 10 kişinin ise $(\% 2,5)$ her zaman kullandığını belirtmiştir.

\section{Tablo 10. Ürün Kategorileri Alışveriş Sıklığı}

\begin{tabular}{llcc}
\hline Ürün Kategorileri Alışveriş Sıklı̆̆ı & & Frekans (F) & Yüzde (\%) \\
\hline \multirow{4}{*}{ Gıda } & Hiçbir zaman & 246 & 61,8 \\
& Nadiren & 72 & 18,1 \\
& Ara sıra & 47 & 11,8 \\
& Sık sık & 19 & 4,8 \\
& Her zaman & 14 & 3,5 \\
\cline { 2 - 4 } & TOPLAM & $\mathbf{3 9 8}$ & $\mathbf{1 0 0}$ \\
\hline \multirow{5}{*}{ Kozmetik } & Hiçbir zaman & 130 & 32,7 \\
& Nadiren & 103 & 25,9 \\
& Ara sıra & 99 & 24,9 \\
& Sik sık & 44 & 11 \\
& Her zaman & 22 & 5,5 \\
\cline { 2 - 4 } & TOPLAM & $\mathbf{3 9 8}$ & $\mathbf{1 0 0}$ \\
\hline \multirow{5}{*}{ Giyim } & Hiçbir zaman & 25 & 6,3 \\
& Nadiren & 68 & 17,1 \\
& Ara sira & 113 & 28,4 \\
& Sik sık & 112 & 28,1 \\
& Her zaman & 80 & 20,1 \\
\cline { 2 - 4 } & TOPLAM & $\mathbf{3 9 8}$ & $\mathbf{1 0 0}$ \\
\hline & Hiçbir zaman & 125 & 31,4 \\
& Nadiren & 116 & 29,1 \\
& Ara sıra & 91 & 22,9 \\
& Sik sık & 41 & 10,3 \\
& Her zaman & 25 & 6,3
\end{tabular}




\begin{tabular}{|c|c|c|c|}
\hline & TOPLAM & 398 & 100 \\
\hline \multirow{6}{*}{ Dergi, Kitap vb. } & Hiçbir zaman & 55 & 13,8 \\
\hline & Nadiren & 77 & 19,3 \\
\hline & Ara sira & 143 & 35,9 \\
\hline & Sik sik & 78 & 19,6 \\
\hline & Her zaman & 45 & 11,4 \\
\hline & TOPLAM & 398 & 100 \\
\hline \multirow{6}{*}{ Tatil, Seyahat, Etkinlik İçin Bilet } & Hiçbir zaman & 200 & 50,3 \\
\hline & Nadiren & 75 & 18,8 \\
\hline & Ara sira & 75 & 18,8 \\
\hline & Sik sık & 19 & 4,8 \\
\hline & Her zaman & 29 & 7,3 \\
\hline & TOPLAM & 398 & 100 \\
\hline \multirow{6}{*}{ Ev/Bahçe Ürünleri } & Hiçbir zaman & 167 & $\overline{42,0}$ \\
\hline & Nadiren & 117 & 29,3 \\
\hline & Ara sira & 74 & 18,6 \\
\hline & Sik sık & 33 & 8,3 \\
\hline & Her zaman & 7 & 1,8 \\
\hline & TOPLAM & 398 & 100 \\
\hline \multirow{6}{*}{ Araba Parçaları } & Hiçbir zaman & 283 & 71,1 \\
\hline & Nadiren & 55 & 13,8 \\
\hline & Ara sira & 31 & 7,8 \\
\hline & Sik sik & 12 & 3,0 \\
\hline & Her zaman & 17 & 4,3 \\
\hline & TOPLAM & 398 & 100 \\
\hline \multirow{6}{*}{ Elektronik ve Ev Eşyaları } & Hiçbir zaman & 134 & 33,7 \\
\hline & Nadiren & 118 & 29,6 \\
\hline & Ara sira & 85 & 21,4 \\
\hline & Sik sik & 36 & 9,0 \\
\hline & Her zaman & 25 & 6,3 \\
\hline & TOPLAM & 398 & 100 \\
\hline
\end{tabular}

Tablo 10'da anket katılımcılarının ürün kategorilerine yönelik alışveriş sıklıklarına bakıldığında; katılımcıların \%61,8'inin (246 kişi) hiç gıda alışverişi yapmadığı, \%3,5'inin ise (14 kişi) her zaman yaptığı görülmektedir. Yine katılımcıların \%37,7'si (130 kişi) hiç kozmetik ürün alışverişi yapmazken \%5'i her zaman yaptığını belirtmiştir. Katılımcılardan 113 kişi ara sıra giyim alışverişi yaparken, 25 kişi hiç giyim alışverişi yapmamaktadır. Sonuçlar aynı zamanda cep telefonu ve aksesuarlarını 125 kişinin internetten hiç almadığını, 25 kişinin her zaman aldığını ve yine dergi, kitap gibi alışverişlerde ise 143 kişinin ara sıra kullanırken 45 kişinin ise hep kullandığını göstermektedir. Ayrıca, tatil, seyahat, etkinlik için bilet alışverişlerinde 200 kişi hiç interneti kullanmazken, 19 kişi sık sık internetten tatil, seyahat, etkinlik için bilet satın aldığını belirtmiştir. Katılımcılardan 167 kişi ev/bahçe ürünleri için hiç internet alışverişi yapmamakla beraber, 7 kişi internetten her zaman ev/bahçe ürünleri satın aldığı görülmektedir. 
Yine sonuçlara 283 kişinin hiçbir zaman araba parçaları alışverişi yapmadığını gösterirken, 12 kişinin sık s1k internetten araba parçası satın aldığını göstermektedir. Son olarak katılımcılardan 134 kişi hiç elektronik ve ev eşyaları alışverişi yapmazken, 25 kişi her zaman elektronik ve ev eşyası satın aldığı görülmektedir.

Tablo 11. İnternette Alışveriş Nedenleri

\begin{tabular}{|c|c|c|c|}
\hline İnternetten Alışveriş Nedenleri & & Frekans (F) & Yüzde (\%) \\
\hline \multirow{6}{*}{ Bol Seçenek Olması } & Hiçbir zaman & 18 & 4,5 \\
\hline & Nadiren & 35 & 8,8 \\
\hline & Ara sira & 75 & 18,8 \\
\hline & Sik sik & 136 & 34,2 \\
\hline & Her zaman & 134 & 33,7 \\
\hline & TOPLAM & 398 & 100 \\
\hline \multirow{6}{*}{ Rahatlık ve Kolaylık } & Hiçbir zaman & 7 & 1,8 \\
\hline & Nadiren & 33 & 8,3 \\
\hline & Ara sira & 85 & 21,4 \\
\hline & Sik sık & 133 & 33,4 \\
\hline & Her zaman & 140 & 35,1 \\
\hline & TOPLAM & 398 & 100 \\
\hline \multirow{6}{*}{ Zaman Kazandırma } & Hiçbir zaman & 37 & 9,3 \\
\hline & Nadiren & 33 & 8,3 \\
\hline & Ara sira & 84 & 21,1 \\
\hline & Sik sik & 114 & 28,6 \\
\hline & Her zaman & 130 & 32,7 \\
\hline & TOPLAM & 398 & 100 \\
\hline \multirow{6}{*}{ Fiyat Avantaj1 } & Hiçbir zaman & 21 & 5,3 \\
\hline & Nadiren & 45 & 11,3 \\
\hline & Ara sira & 69 & 17,3 \\
\hline & Sık sık & 120 & 30,2 \\
\hline & Her zaman & 143 & 35,9 \\
\hline & TOPLAM & 398 & 100 \\
\hline \multirow{6}{*}{ Güvenilir Olması } & Hiçbir zaman & 30 & 7,5 \\
\hline & Nadiren & 82 & 20,6 \\
\hline & Ara sira & 122 & 30,7 \\
\hline & Sik sık & 89 & 22,4 \\
\hline & Her zaman & 75 & 18,8 \\
\hline & TOPLAM & 398 & 100 \\
\hline \multirow{6}{*}{ Karşılaştırma Yapılabilmesi } & Hiçbir zaman & 27 & 6,8 \\
\hline & Nadiren & 37 & 9,3 \\
\hline & Ara sira & 83 & 20,9 \\
\hline & Sik sik & 124 & 31,2 \\
\hline & Her zaman & 127 & 31,8 \\
\hline & TOPLAM & 398 & 100 \\
\hline \multirow{2}{*}{ Fiziki Temas Gerektirmemesi } & Hiçbir zaman & 29 & 7,3 \\
\hline & Nadiren & 58 & 14,6 \\
\hline
\end{tabular}




\begin{tabular}{lcc} 
Ara sira & 70 & 17,6 \\
S1k s1k & 114 & 28,6 \\
Her zaman & 127 & 31,9 \\
\hline TOPLAM & $\mathbf{3 9 8}$ & $\mathbf{1 0 0}$
\end{tabular}

Tablo 11'de katılımcıların internetten alışveriş nedenleri incelendiğinde; bol seçenek olması nedeniyle 134 kişinin $(\% 33,7)$ her zaman, 18 kişinin $(\% 4,5)$ hiçbir zaman; rahatlık ve kolaylık için 140 kişinin $(\% 35,2)$ her zaman, 7 kişinin $(\% 1,8)$ hiçbir zaman; zaman kazandırması nedeniyle 130 kişinin $(\% 32,7)$ her zaman, 33 kişinin $(\% 8,3)$ nadiren; fiyat avantajı olması nedeniyle 143 kişinin $(\% 35,9)$ her zaman, 21 kişinin $(\% 5,3)$ hiçbir zaman; güvenilir olması nedeniyle 122 kişinin $(\% 30,7)$ ara sıra, 30 kişinin $(\% 7,5)$ hiçbir zaman; karşılaştırma yapılabilmesi nedeniyle 127 kişinin $(\% 31,9)$ her zaman, 27 kişinin $(\% 6,8)$ hiçbir zaman; fiziki temas gerektirmemesi nedeniyle 127 kişinin $(\% 31,9)$ her zaman, 29 kişinin $(\% 7,3)$ hiçbir zaman cevaplarını verdikleri görülmektedir.

\section{Değişkenler Arasındaki İlişkilere Ait Korelasyon Bulguları}

Bu kısımda, algılanan e-hizmet kalitesi boyutunun alt boyutları ile müşteri tatmini ve müşteri sadakati boyutları arasındaki ilişkileri gösteren korelasyon analizi bulgularına yer verilmiştir.

Tablo 12. Algılanan e-Hizmet Kalitesi Boyutunun Alt Boyutları, Müşteri Tatmini ve Müşsteri Sadakati Değişkenlerine İlişkin Korelasyon Analizi Sonuçları

\begin{tabular}{|c|c|c|c|c|c|c|c|c|c|c|c|}
\hline \multicolumn{3}{|c|}{ Değişkenler / Alt Boyutlar } & 1 & 2 & 3 & 4 & 5 & 6 & 7 & 8 & 9 \\
\hline \multirow{4}{*}{ 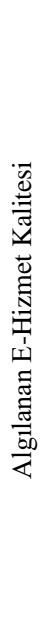 } & $\begin{array}{l}\text { Web Sayfasının } \\
\text { Verimliliği ve } \\
\text { Kullanılabilirliği } \\
\text { (1) }\end{array}$ & $\begin{array}{l}\text { Pearson } \\
\text { Corr. } \\
\text { Sig.(2- } \\
\text { tailed) }\end{array}$ & 1 & & & & & & & & \\
\hline & $\begin{array}{c}\text { Web Sayfasının } \\
\text { Tasarımı } \\
\text { (2) }\end{array}$ & $\begin{array}{l}\text { Pearson } \\
\text { Corr. } \\
\text { Sig.(2- } \\
\text { tailed) }\end{array}$ & $\begin{array}{c}, 716^{* * *} \\
, 000\end{array}$ & 1 & & & & & & & \\
\hline & $\begin{array}{l}\text { Bilgi Kalitesi } \\
\text { (3) }\end{array}$ & $\begin{array}{l}\text { Pearson } \\
\text { Corr. } \\
\text { Sig.(2- } \\
\text { tailed) }\end{array}$ & $\begin{array}{l}, 739 * * \\
, 000\end{array}$ & $\begin{array}{l}, 652 * * \\
, 000\end{array}$ & 1 & & & & & & \\
\hline & $\begin{array}{l}\text { Yerine Getirme } \\
\text { (4) }\end{array}$ & $\begin{array}{l}\text { Pearson } \\
\text { Corr. } \\
\text { Sig.(2- } \\
\text { tailed) }\end{array}$ & $\begin{array}{l}, 629 * * \\
, 000\end{array}$ & $\begin{array}{l}, 578 * * \\
, 000\end{array}$ & $\begin{array}{l}, 692 * * \\
, 000\end{array}$ & 1 & & & & & \\
\hline
\end{tabular}




\section{A.Yıldız-S.Kuyucu Internet Alısverislerinde Algılanan E-Hizmet...}

\begin{tabular}{|c|c|c|c|c|c|c|c|c|c|c|}
\hline \multirow{2}{*}{$\begin{array}{l}\text { Güvence } \\
\text { (5) }\end{array}$} & $\begin{array}{l}\text { Pearson } \\
\text { Corr. }\end{array}$ &, $504 * *$ &, $500 * *$ &, $695^{* *}$ &, $651 * *$ & 1 & & & & \\
\hline & $\begin{array}{l}\text { Sig.(2- } \\
\text { tailed) }\end{array}$ & ,000 & ,000 & ,021 & ,000 & & & & & \\
\hline \multirow{2}{*}{$\begin{array}{c}\text { Müşteri } \\
\text { Hizmetleri } \\
\text { (6) }\end{array}$} & $\begin{array}{l}\text { Pearson } \\
\text { Corr. }\end{array}$ &, $576^{* * *}$ & $529 * *$ & ,694** &, $650 * *$ &, $660 * *$ & 1 & & & \\
\hline & $\begin{array}{l}\text { Sig.(2- } \\
\text { tailed) }\end{array}$ & ,000 & ,001 & ,000 & ,000 & ,000 & & & & \\
\hline \multirow{2}{*}{$\begin{array}{l}\text { Sipariş } \\
\text { Yönetimi } \\
\text { (7) }\end{array}$} & $\begin{array}{l}\text { Pearson } \\
\text { Corr. }\end{array}$ &, $656^{* * *}$ &, $521^{* *}$ & ,688* & $747 * *$ &, $626 * *$ &, $765 * *$ & 1 & & \\
\hline & $\begin{array}{l}\text { Sig.(2- } \\
\text { tailed) }\end{array}$ & ,000 & ,000 & ,000 & ,000 & ,000 & ,000 & & & \\
\hline \multirow{2}{*}{$\begin{array}{l}\text { Müşteri Tatmini } \\
\text { (8) }\end{array}$} & $\begin{array}{l}\text { Pearson } \\
\text { Corr. }\end{array}$ &, $656^{* * *}$ &, $560 * *$ &, $682 * *$ & $678^{* *}$ &, $709 * *$ &, $712 * *$ &, $748 * *$ & 1 & \\
\hline & $\begin{array}{l}\text { Sig.(2- } \\
\text { tailed) }\end{array}$ & ,000 & ,000 & ,000 & ,000 & ,000 & ,000 & ,000 & & \\
\hline \multirow{2}{*}{$\begin{array}{l}\text { Müşteri Sadakati } \\
\text { (9) }\end{array}$} & $\begin{array}{l}\text { Pearson } \\
\text { Corr. }\end{array}$ &, $610 * *$ &, $477 * *$ &, $578 * *$ &, $583^{* *}$ &, $559 * *$ &, $641 * *$ &, $646^{* * *}$ &, $684 * *$ & 1 \\
\hline & $\begin{array}{l}\text { Sig.(2- } \\
\text { tailed) }\end{array}$ & ,000 & ,000 & ,000 & ,000 & ,000 & ,000 & ,000 & ,000 & \\
\hline
\end{tabular}

** $\mathrm{P} \leq 0,01$ : Korelasyon düzeyi için anlamlıdır.

Tablo 12'de görüldüğü gibi, tüm değişkenler arasında anlamlı bir ilişki vardır $(\mathrm{p}<0,01)$.

Analiz sonuçları incelendiğinde; web sayfasının verimliliği ve kullanılabilirliği ile web sayfasının tasarımı arasındaki korelasyon katsayısı değeri $\mathrm{r}=, 716$ olarak bulunmuştur. Buna göre web sayfasının verimliliği ve kullanılabilirliği ile web sayfasının tasarımı arasında güçlü derecede anlamlı bir ilişki bulunmuştur. Web sayfasının verimliliği ve kullanılabilirliği ile bilgi kalitesi arasındaki korelasyon katsayısı değeri $\mathrm{r}=, 739$ olarak bulunmuştur. Buna göre web sayfasının verimliliği ve kullanılabilirliği ile bilgi kalitesi arasında güçlü derecede anlamlı bir ilişki bulunmuştur. Web sayfasının tasarımı ile bilgi kalitesi arasındaki korelasyon katsayısı değeri $r=, 652$ olarak bulunmuştur. Buna göre web sayfasının tasarımı ile bilgi kalitesi arasında orta derecede anlamlı bir ilişki bulunmuştur. Web sayfasının verimliliği ve kullanılabilirliği ile yerine getirme arasındaki korelasyon katsayısı değeri $r=, 629$ olarak bulunmuştur. Buna göre web sayfasının verimliliği ve kullanılabilirliği ile yerine getirme arasında orta derecede anlamlı bir ilişki bulunmuştur. Web sayfasının tasarımı ile yerine getirme arasındaki korelasyon katsayısı değeri $\mathrm{r}=, 578$ olarak bulunmuştur. Buna göre web sayfasının tasarımı arasında orta derecede anlamlı bir ilişki bulunmuştur. Bilgi kalitesi ile yerine getirme arasındaki korelasyon katsayısı değeri $r=, 692$ olarak bulunmuştur. Buna göre bilgi kalitesi ile yerine getirme arasında orta derecede anlamlı bir ilişki bulunmuştur. Web sayfasının verimliliği 
ve kullanılabilirliği ile güvence arasındaki korelasyon katsayısı değeri $r=, 504$ olarak bulunmuştur. Buna göre web sayfasının verimliliği ve kullanılabilirliği ile güvence arasında orta derecede anlamlı bir ilişki bulunmuştur. Web sayfasının tasarımı arasındaki korelasyon katsayısı değeri $\mathrm{r}=, 500$ olarak bulunmuştur. Buna göre web sayfasının tasarımı ile güvence arasında orta derecede anlamlı bir ilişki bulunmuştur. Yerine getirme ile güvence arasındaki korelasyon katsayısı değeri $\mathrm{r}=, 651$ olarak bulunmuştur. Buna göre yerine getirme ile güvence arasında orta derecede anlamlı bir ilişki bulunmuştur. Web sayfasının verimliliği ve kullanılabilirliği müşteri hizmetleri arasındaki korelasyon katsayısı değeri $\mathrm{r}=, 576$ olarak bulunmuştur. Buna göre web sayfasının verimliliği ve kullanılabilirliği ile müşteri hizmetleri arasında orta derecede anlamlı bir ilişki bulunmuştur. Web sayfasının tasarımı ile müşteri hizmetleri arasındaki korelasyon katsayısı değeri $\mathrm{r}=, 529$ olarak bulunmuştur. Buna göre web sayfasının tasarımı ile müşteri hizmetleri arasında orta derecede anlamlı bir ilişki bulunmuştur. Bilgi kalitesi ile müşteri hizmetleri arasındaki korelasyon katsayısı değeri $\mathrm{r}=, 694$ olarak bulunmuştur. Buna göre bilgi kalitesi ile müşteri hizmetleri arasında orta derecede anlamlı bir ilişki bulunmuştur. Yerine getirme ile müşteri hizmetleri arasındaki korelasyon katsayısı değeri $\mathrm{r}=, 650$ olarak bulunmuştur. Buna göre yerine getirme ile müşteri hizmetleri arasında orta derecede anlamlı bir ilişki bulunmuştur. Güvence ile müşteri hizmetleri arasındaki korelasyon katsayısı değeri $r=, 660$ olarak bulunmuştur. Buna göre güvence ile müşteri hizmetleri arasında orta derecede anlamlı bir ilişki bulunmuştur. Web sayfasının verimliliği ve kullanılabilirliği ile sipariş yönetimi arasındaki korelasyon katsayısı değeri $\mathrm{r}=, 656$ olarak bulunmuştur. Buna göre web sayfasının verimliliği ve kullanılabilirliği ile sipariş yönetimi arasında orta derecede anlamlı bir ilişki bulunmuştur. Web sayfasının tasarımı ile sipariş yönetimi arasındaki korelasyon katsayısı değeri $r=, 521$ olarak bulunmuştur. Buna göre web sayfasının tasarımı ile sipariş yönetimi arasında orta derecede anlamlı bir ilişki bulunmuştur. Bilgi kalitesi ve sipariş yönetimi arasındaki korelasyon katsayısı değeri $\mathrm{r}=, 688$ olarak bulunmuştur. Buna göre bilgi kalitesi ve sipariş yönetimi arasında orta derecede anlamlı bir ilişki bulunmuştur. Yerine getirme ile sipariş yönetimi arasındaki korelasyon katsayısı değeri $\mathrm{r}=, 747$ olarak bulunmuştur. Buna göre yerine getirme ile sipariş yönetimi arasında yüksek derecede anlamlı bir ilişki bulunmuştur. Güvence ile sipariş yönetimi arasındaki korelasyon katsayısı değeri $r=, 626$ olarak bulunmuştur. Buna göre güvence ile sipariş yönetimi arasında orta derecede anlamlı bir ilişki bulunmuştur. Müşteri hizmetleri ile sipariş yönetimi arasındaki korelasyon katsayısı değeri $\mathrm{r}=, 765$ olarak bulunmuştur. Buna göre müşteri hizmetleri ile sipariş yönetimi arasında yüksek derecede anlamlı bir ilişki bulunmuştur. Web sayfasının verimliliği ve kullanılabilirliği ile müşteri tatmini arasındaki korelasyon katsayısı değeri $r=, 656$ olarak bulunmuştur. Buna göre web sayfasının verimliliği ve kullanılabilirliği ile müşteri tatmini arasında orta derecede anlamlı bir ilişki bulunmuştur. Web sayfasının tasarımı ile müşteri tatmini arasındaki korelasyon katsayısı değeri $r=, 560$ olarak bulunmuştur. Buna 


\section{A.Yıldız-S.Kuyucu Internet Alısverislerinde Algılanan E-Hizmet...}

göre web sayfasının tasarımı ile müşteri tatmini arasında orta derecede anlamlı bir ilişki bulunmuştur. Bilgi kalitesi ile müşteri tatmini arasındaki korelasyon katsayısı değeri $r=, 682$ olarak bulunmuştur. Buna göre bilgi kalitesi ile müşteri tatmini arasında orta derecede anlamlı bir ilişki bulunmuştur. Yerine getirme ile müşteri tatmini arasındaki korelasyon katsayısı değeri $\mathrm{r}=, 678$ olarak bulunmuştur. Buna göre yerine getirme ile müşteri tatmini arasında orta derecede anlamlı bir ilişki bulunmuştur. Güvence ile müşteri tatmini arasındaki korelasyon katsayısı değeri $r=, 709$ olarak bulunmuştur. Buna göre güvence ile müşteri tatmini arasında yüksek derecede anlamlı bir ilişki bulunmuştur. Müşteri hizmetleri ile müş̧eri tatmini arasındaki korelasyon katsayısı değeri $r=, 712$ olarak bulunmuştur. Buna göre müşteri hizmetleri ile müşteri tatmini arasında yüksek derecede anlamlı bir ilişki bulunmuştur. Sipariş yönetimi ile müşteri tatmini arasındaki korelasyon katsayısı değeri $r=, 748$ olarak bulunmuştur. Buna göre sipariş yönetimi ile müşteri tatmini arasında yüksek derecede anlamlı bir ilişki bulunmuştur. Web sayfasının verimliliği ve kullanılabilirliği ile müşteri sadakati arasındaki korelasyon katsayısı değeri $\mathrm{r}=, 610$ olarak bulunmuştur. Buna göre web sayfasının verimliliği ve kullanılabilirliği ile müşteri sadakati arasında orta derecede anlamlı bir ilişki bulunmuştur. Web sayfasının tasarımı ile müşteri sadakati arasındaki korelasyon katsayısı değeri $r=, 477$ olarak bulunmuştur. Buna göre web sayfasının tasarımı ile müşteri sadakati arasında orta derecede anlamlı bir ilişki bulunmuştur. Bilgi kalitesi ile müşteri sadakati arasındaki korelasyon katsayısı değeri $r=, 578$ olarak bulunmuştur. Buna göre bilgi kalitesi ile müşteri sadakati arasında orta derecede anlamlı bir ilişki bulunmuştur. Yerine getirme ile müşteri sadakati arasındaki korelasyon katsayısı değeri $\mathrm{r}=, 583$ olarak bulunmuştur. Buna göre yerine getirme ile müşteri sadakati arasında orta derecede anlamlı bir ilişki bulunmuştur. Güvence ile müşteri sadakati arasındaki korelasyon katsayısı değeri $r=, 559$ olarak bulunmuştur. Buna göre güvence ile müşteri sadakati arasında orta derecede anlamlı bir ilişki bulunmuştur. Müşteri hizmetleri ile müşteri sadakati arasındaki korelasyon katsayısı değeri $r=, 641$ olarak bulunmuştur. Buna göre müşteri hizmetleri ile müşteri sadakati arasında orta derecede anlamlı bir ilişki bulunmuştur. Sipariş yönetimi ile müşteri sadakati arasındaki korelasyon katsayısı değeri $\mathrm{r}=, 646$ olarak bulunmuştur. Buna göre sipariş yönetimi ile müşteri sadakati arasında orta derecede anlamlı bir ilişki bulunmuştur. Müsşeri tatmini ile müşteri sadakati arasındaki korelasyon katsayısı değeri $r=, 684$ olarak bulunmuştur. Buna göre müssteri tatmini ile müşteri sadakati arasında orta derecede anlamlı bir ilişki bulunmuştur.

Katılımcıların korelasyon analizi sonuçlarına göre $\mathbf{H}_{\mathbf{1}}$ hipotezi (Adıyaman Üniversitesi öğrencilerinin internet alışverişlerinde algıladıkları e-hizmet kalitesi ve müşteri tatmini arasında pozitif yönlü anlamlı bir ilişki vardır) kabul edilmiştir. İnternet alışverişlerinde algilanan e-hizmet kalitesi ve müşteri tatmini arasında istatistiksel olarak pozitif yönlü ve orta derecede anlamlı bir ilişki vardır. 
Katılımcıların korelasyon analizi sonuçlarına göre $\mathbf{H}_{\mathbf{2}}$ hipotezi (Adıyaman Üniversitesi öğrencilerinin internet alışverişlerinde algıladıkları e-hizmet kalitesi ve müşteri sadakati arasında pozitif yönlü anlamlı bir ilişki vardır) kabul edilmiştir. İnternet alışverişlerinde algılanan e-hizmet kalitesi ve müşteri sadakati arasında istatistiksel olarak pozitif yönlü ve orta derecede anlamlı bir ilişki vardır.

Katılımcıların korelasyon analizi sonuçlarına göre $\mathbf{H}_{3}$ hipotezi (Adıyaman Üniversitesi öğrencilerinin internet alışverişlerinde müşteri tatmini ile müşteri sadakati arasında pozitif yönlü anlamlı bir iliş̧ki vardır) kabul edilmiştir. İnternet alışverişlerinde müşteri tatmini ve müşteri sadakati arasında istatistiksel olarak pozitif yönlü ve orta derecede anlamlı bir ilişki vardır.

\section{TARTIŞMA ve SONUÇLAR}

Günümüz yoğun çalışma ortamı, şehir trafiği, kadınların iş hayatında daha çok yer almaya başlaması zamanı daha değerli kılmış ve insanları internet kullanımına yönlendirmiştir. Son zamanlarda özellikle sanal mağazacılık boyutuna geçiş hem işletmeler hem de tüketiciler açısından birçok değişime neden olmuştur. İşletmeler bu yeni gelişmelerin farkına varmışlardır. Tüketicilerin ürüne ve ürün bilgisine kolay ulaşıyor olması, fiyat karşılaştırması yapması; işletmeleri tüketici istek ve ihtiyaçlarını daha çok önemsemeye zorlamıştır.

E-hizmetlerde de tıpkı geleneksel hizmetlerde olduğu gibi müşteri tatmini ve müşteri sadakati, işletmelerin gerek rekabet açısından avantaj sağlamaları gerekse işletmenin sürekliliği devamlılığının sağlanması açısından önem teşkil etmektedir. Literatürde hizmet kalitesinin ölçen birçok çalışma olsa da algılanan e-hizmet kalitesinin 7 alt boyutu (web sayfasının verimliliği ve kullanılabilirliği, web sayfasının tasarımı, bilgi kalitesi, vaatleri yerine getirme, güvence, müşteri hizmetleri ve sipariş yönetimi), müşteri tatmini ve müşteri sadakati arasındaki ilişkiyi ölçmeye dönük olması, bu çalışmanın en temel özgün değerini oluşturmaktadır.

İnternet üzerinden yapılan alışverişlerde algılanan e-hizmet kalitesi, müşteri tatmini ve müşteri sadakati arasındaki ilişkinin analiz edildiği bu çalışmada elde edilen sonuçlar şu şekilde özetlenebilir:

- Demografik değişkenler bakımından; katılımcıların \%57,5'i kadınlardan; $\% 42,5$ 'i ise erkeklerden oluşmaktadır. Yaş değişkeni bakımından katılımcıların \%80,9'unun 20-26 yaş aralığında olduğu görülmektedir. Eğitim düzeyi açısından ise katılımc1ların \%49,7'si önlisans, \%45'i lisans, \%5'3’ü ise lisansüstü eğitim düzeyindeki öğrencilerdir. Sınıf düzeyi bakımından hazırlık sınıfında okuyan öğrenci oranı $(\% 0,8)$ ile 5 . ve 6 . Sinıfta okuyan öğrenci oranının $(\% 1,8)$ düşük 
olduğu görülmektedir. Bunun nedeni hazırlık sınıfı olan ya da 5-6 yıllık eğitim süresine sahip bölüm sayısının az olması şeklinde ifade edilebilir. Katılımcıların gelir düzeyleri genellikle asgari ücret ve aşağısındadır.

- Katılımcılar genellikle birkaç ayda bir internet üzerinden alışveriş yapmakta olup, katılımcıların bir yıl içerisinde internet üzerinden satın aldıkları ürünlere ilişkin harcadıkları tutar $1000 \mathrm{TL}$ ve aşağısıdır.

- Katılımcıların \%29,6'sı gün içerisinde ortalama 3-4 saat, \%27,4'ü 5-6 saat zaman geçirmektedir.

- Katılımcılardan müzik dinlemek amaciyla sık sık ya da her zaman interneti kullananların oranı toplamda \%62,1'dir. Sosyal medyayı takip etmek için sık sık ya da her zaman interneti kullananların oranı ise \%71,6'dır. Özellikle pandemi döneminde uzaktan (online) eğitime devam etmek için sık sık ya da her zaman interneti kullananların oranı ise \%82,4'tür.

- En fazla kullanılan (sık sık + her zaman) alışverişs sitesi ya da uygulaması, $\% 57,8$ 'lik bir oran ile trendyol'dur.

- İnternet üzerinden en fazla (sık sık + her zaman) alışveriş yapılan ürün grubu, $\% 48,2$ ile giyim ürünleri grubudur.

- Katılımcıların internet üzerinden alışveriş yapmalarının en büyük sebepler (sık sık + her zaman); rahatlık ve kolaylık $(\% 68,6)$, bol seçenek olması $(\% 67,9)$ ve fiyat avantaj $1(\% 66,1)$ 'dir.

- Ankete katılanlar arasında internetten alışveriş̧ yapmayanların da olduğu görülmektedir. Araştırmanın, üniversite öğrencileri üzerinde yapıldığı dikkate alındığında bu kesim, bilgisayar teknolojisi ve internet kullanımına aşina olduğu fakat çoğunluğun çalışma yoluyla gelir elde edememelerinin ve özellikle üniversiteye yeni başlayanların ve bireysel alışveriş konusunda zorluğu olanların tüketim harcamaları üzerinde etkisinin yüksek olduğu görülmektedir. Bununla birlikte, yaş ortalaması ve gelir düzeyi yüksek olanların daha tecrübeli ve internetten alışveriş konusunda daha korkusuz oldukları söylenebilir.

- Bu bağlamda benzer çalışmalar incelendiğinde internet kullanıcılarının büyük çoğunluğunun artık online alışverişe karşı ön yargısının ortadan kalktı̆̆1 az miktarda bile olsa internetten alışverişi kullandığ 1 belirlenmiştir. $\mathrm{Bu}$ önyargıların yerini güvene bırakmasında, internet sitelerinin tüketici haklarını korumaya yönelik gizlilik politikalarına yer vermeleri ve ödeme sırasında güvenli ödeme seçeneklerinin olması, mesafeli satı̧s sözleşmelerine ve ön bilgilendirme formlarına yer vermelerinin tereddütlere yumuşatıcı etki yaptığı söylenebilir. 
- Katılımcıların en çok tercih ettikleri alışveriş siteleri ile ilgili olarak; site kullanımının basit olduğu, kolay ve hızlı şekilde işlem yapabildikleri, satın alma işlemi sırasında ve sonrasında ürün ile ilgili sorun yaşamadıkları, kişisel bilgilerin ve kredi kartı bilgilerinin korunması konusunda müşterilere güven verdikleri, satın alma sonrasında hizmet ve yardım, iade, tazminat ve garanti gibi konularda her türlü desteğin verildiği, sipariş yönetimi sistemlerinin iyi olduğu ifade edilmektedir.

- Yapılan korelasyon analizi neticesinde; algılanan e-hizmet kalitesi boyutunun web sayfasının verimliliği ve kullanılabilirliği alt boyutu ile web sayfasının tasarımı alt boyutu arasında pozitif yönde güçlü derecede; web sayfasının verimliliği ve kullanılabilirliği ile bilgi kalitesi arasında pozitif yönde güçlü derecede; web sayfasının tasarımı ile bilgi kalitesi arasında pozitif yönde orta derecede; web sayfasının verimliliği ve kullanılabilirliği ile vaatleri yerine getirme arasında pozitif yönde orta derecede; web sayfasının tasarımı ile vaatleri yerine getirme arasinda pozitif yönde orta derecede; bilgi kalitesi ile vaatleri yerine getirme arasında pozitif yönde orta derecede; web sayfasının verimliliği ve kullanılabilirliği ile güvence arasında pozitif yönde orta derecede; web sayfasının tasarımı ile güvence arasında pozitif yönde orta derecede; vaatleri yerine getirme ile güvence arasında pozitif yönde orta derecede; web sayfasının verimliliği ve kullanılabilirliği ile müşteri hizmetleri arasında pozitif yönde orta derecede; web sayfasının tasarımı ile müşteri hizmetleri arasında, pozitif yönde orta derecede; bilgi kalitesi ile müşteri hizmetleri arasında, pozitif yönde orta derecede; vaatleri yerine getirme ile müssteri hizmetleri arasında pozitif yönde orta derecede güvence ile müşteri hizmetleri arasında, pozitif yönde orta derecede; web sayfasının verimliliği ve kullanılabilirliği ile sipariş yönetimi arasında pozitif yönde orta derecede; web sayfasının tasarımı ile sipariş yönetimi arasında, pozitif yönde orta derecede; bilgi kalitesi ile sipariş yönetimi arasında pozitif yönde orta derecede; vaatleri yerine getirme ile sipariş yönetimi arasında pozitif yönde yüksek derecede; güvence ile sipariş yönetimi arasında pozitif yönde orta derecede; müşteri hizmetleri ile sipariş yönetimi arasında pozitif yönde yüksek derecede; web sayfasının verimliliği ve kullanılabilirliği ile müşteri tatmini arasında pozitif yönde orta derecede; web sayfasının tasarımı ile müşteri tatmini arasında pozitif yönde orta derecede; bilgi kalitesi ile müşteri tatmini arasında pozitif yönde orta derecede; vaatleri yerine getirme ile müşteri tatmini arasında pozitif yönde orta derecede; güvence ile müşteri tatmini arasında pozitif yönde yüksek derecede; müşteri hizmetleri ile müşseri tatmini arasında pozitif yönde yüksek derecede; Sipariş yönetimi ile müşteri tatmini arasında pozitif yönde yüksek derecede; web sayfasının verimliliği ve kullanılabilirliği ile müşteri sadakati arasında pozitif yönde orta derecede; web sayfasının tasarımı ile müşteri sadakati arasında pozitif yönde orta derecede; Bilgi kalitesi ile müşteri sadakati arasında pozitif yönde orta derecede; vaatleri yerine getirme ile müşteri sadakati arasında pozitif yönde orta derecede; güvence ile müşteri sadakati arasında pozitif 


\section{A.Yıldız-S.Kuyucu Internet Alısverislerinde Algılanan E-Hizmet...}

yönde orta derecede; müşteri hizmetleri ile müşteri sadakati arasında pozitif yönde orta derecede; sipariş yönetimi ile müşteri sadakati arasında pozitif yönde orta derecede; müşteri tatmini ile müşteri sadakati arasında pozitif yönde orta derecede anlamlı bir ilişki bulunmuştur.

$\mathrm{Bu}$ doğrultuda araştırmanın soruları, hipotezler, beklenen sonuçlar ve gerçekleşen sonuçlara ilişkin bilgiler Tablo 13'te verilmiştir.

Tablo 13. Araştırma Soruları, Hipotezler, Beklenen Sonuçlar ve Gerçekleşen Sonuçlar

\begin{tabular}{|c|c|c|c|c|}
\hline $\begin{array}{l}\text { Sira } \\
\text { No }\end{array}$ & $\begin{array}{c}\text { Araştırmanın } \\
\text { Soruları }\end{array}$ & Hipotezler & Beklenen Sonuçlar & $\begin{array}{c}\text { Gerçekleşen } \\
\text { Sonuçlar }\end{array}$ \\
\hline 1 & $\begin{array}{l}\text { Adıyaman } \\
\text { Üniversitesi } \\
\text { öğrencilerinin } \\
\text { internet } \\
\text { alışverişlerinde } \\
\text { algıladıkları e- } \\
\text { hizmet kalitesi ve } \\
\text { müşteri tatmini } \\
\text { arasında bir ilişki } \\
\text { var mıdır? }\end{array}$ & $\begin{array}{l}\text { H}_{1}: \quad \text { Adıyaman } \\
\text { Üniversitesi } \\
\text { öğrencilerinin } \\
\text { internet } \\
\text { alışverişlerinde } \\
\text { algıladıkları e- } \\
\text { hizmet kalitesi ve } \\
\text { müşteri tatmini } \\
\text { arasında pozitif } \\
\text { yönlü anlamlı bir } \\
\text { ilişki vardır. }\end{array}$ & $\begin{array}{l}\text { Adıyaman } \\
\text { Üniversitesi } \\
\text { öğrencilerinin } \\
\text { internet } \\
\text { alışverişlerinde } \\
\text { algıladıkları e- } \\
\text { hizmet kalitesi ve } \\
\text { müşteri tatmini } \\
\text { arasında pozitif } \\
\text { yönlü anlamlı bir } \\
\text { ilişki vardır. }\end{array}$ & $\begin{array}{l}\text { Adıyaman } \\
\text { Üniversitesi } \\
\text { öğrencilerinin } \\
\text { internet } \\
\text { alışverişlerinde } \\
\text { algıladıkları } \\
\text { hizmet kalitesi } \\
\text { müşteri } \quad \text { ve } \\
\text { arasıtnda pozitif } \\
\text { yönlü anlamlı bir } \\
\text { ilişki r } \\
\text { edilmiştir. } \\
\text { hipotezi } \\
\text { edilmiştir. }\end{array}$ \\
\hline 2 & $\begin{array}{l}\text { Adıyaman } \\
\text { Üniversitesi } \\
\text { öğrencilerinin } \\
\text { internet } \\
\text { alışverişlerinde } \\
\text { algıladıkları e- } \\
\text { hizmet kalitesi ve } \\
\text { müşteri sadakati } \\
\text { arasında bir ilişki } \\
\text { var mıdır? }\end{array}$ & $\begin{array}{l}\mathrm{H}_{2} \text { : Adıyaman } \\
\text { Üniversitesi } \\
\text { öğrencilerinin } \\
\text { internet } \\
\text { alışverişlerinde } \\
\text { algıladıkları e- } \\
\text { hizmet kalitesi ve } \\
\text { müşteri sadakati } \\
\text { arasında pozitif } \\
\text { yönlü anlamlı bir } \\
\text { ilişki vardır. }\end{array}$ & $\begin{array}{l}\text { Adıyaman } \\
\text { Üniversitesi } \\
\text { öğrencilerinin } \\
\text { internet } \\
\text { alışverişlerinde } \\
\text { algıladıkları e- } \\
\text { hizmet kalitesi ve } \\
\text { müşteri sadakati } \\
\text { arasında pozitif } \\
\text { yönlü anlamlı bir } \\
\text { ilişki vardır. }\end{array}$ & 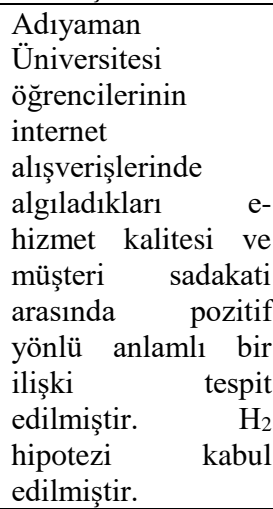 \\
\hline 3 & $\begin{array}{l}\text { Adıyaman } \\
\text { Üniversitesi } \\
\text { öğrencilerinin } \\
\text { internet } \\
\text { alışverişlerinde } \\
\text { müş̧teri tatmini ile } \\
\text { müşteri sadakati } \\
\text { arasında bir ilişki } \\
\text { var mıdır? }\end{array}$ & $\begin{array}{l}\mathrm{H}_{3}: \quad \text { Adıyaman } \\
\text { Üniversitesi } \\
\text { öğrencilerinin } \\
\text { internet } \\
\text { alışverişlerinde } \\
\text { müşteri tatmini ile } \\
\text { müşteri sadakati } \\
\text { arasında pozitif }\end{array}$ & $\begin{array}{l}\text { Adıyaman } \\
\text { Üniversitesi } \\
\text { öğrencilerinin } \\
\text { internet } \\
\text { alışverişlerinde } \\
\text { müşteri tatmini ile } \\
\text { müşteri sadakati } \\
\text { arasında pozitif }\end{array}$ & $\begin{array}{l}\text { Adıyaman } \\
\text { Üniversitesi } \\
\text { öğrencilerinin } \\
\text { internet } \\
\text { alışverişlerinde } \\
\text { müşteri tatmini ile } \\
\text { müşteri sadakati } \\
\text { arasında pozitif } \\
\text { yönlü anlamlı bir }\end{array}$ \\
\hline
\end{tabular}




\begin{tabular}{lllll}
\hline yönlü anlamlı bir & $\begin{array}{l}\text { yönlü anlamlı bir } \\
\text { ilişşi vardır. }\end{array}$ & & $\begin{array}{l}\text { ilişki vardır. } \\
\text { edilmiştir. } \\
\text { hipotezi } \\
\text { edilmiştir. }\end{array}$ & $\begin{array}{r}\text { tespit } \\
\mathrm{H}_{3} \\
\text { kabul }\end{array}$ \\
\hline
\end{tabular}

Kaynak: Çelik, M. (2012).

Tüketicilerin, farklı alternatifler arasında her zaman kendilerine daha çok fayda sağlayacak ürünleri tercih edecekleri bilinmelidir (Aslan ve Özbeyaz, 2019: 1987). İnternet teknolojisinde yaşanan hızl gelişmeye ayak uydurabilmek amacıyla işletmeler, müşteri hizmetleri, online ürün bilgisi arama ve satın alma, ürünler arası karşılaştırma yapabilme gibi birçok özelliği internet alışverişi ortamlarına eklemişlerdir. İnternette sunulan bu hizmetlerin de geleneksel hizmetlerde olduğu gibi kaliteli olarak sunulması önem arz etmektedir.

$\mathrm{Bu}$ bağlamda e-ticaret konusunda hiç deneyimi olmayan işletmelerin, eticarete yönelmeden önce mevcut altyapısını gözden geçirip, doğru pazar araştırmaları yapmaları gerekmektedir.

Pazarlama uygulamalarında başarı yakalayabilmek için doğru müşteri analizi yapmak ve doğru hedef kitle belirlemek son derece önemlidir. E-ticaret uygulamalarında da durum aynı olmaktadır. Mevcut pazara ait müşteri analizleri yeni bir pazara yönelme konusunda aynı başarıyı göstermeyebilir. Özellikle farklı demografik yapıdaki tüketiciler için istek ve ihtiyaçlar da farklılık gösterebilecektir. Yapılan araştırmalar ve elde edilen bulgular neticesinde, işletmelere yönelik sunulabilecek öneriler şu şekilde sıralanabilir:

- İşletmeler, bilgi teknolojileri sayesinde sanal mağazalarını geleneksel mağaza gibi dizayn edebilmelilerdir. İşletmelerin yenilikleri takip etmesi ve sanal ortamda ürün deneyebilme özelliği gibi birtakım uygulamalar geliştirmesi, internetten alışveriş konusunda hala devam etmekte olan önyargılara çözüm oluşturabilecektir.

- İşletmeler, online alışverişi teşvik edecek ve kolaylaştıracak birtakım mobil uygulamalar geliştirebilmelidir.

- Katılımcıların büyük çoğunluğunun sosyal medyayı aktif bir şekilde kullandığı görüldüğünden, işletmeler sosyal medyada çok daha fazla yer alabilmeli, yeni neslin diline uygun bir dil kullanabilmelidir.

- İnternet üzerinden en fazla alışveriş yapılan ürün grubunun giyim ürünleri grubu olduğu dikkate alındığında, bu sektördeki rekabetin daha fazla artacağına dikkat edilmeli, diğer ürün gruplarına yönelik online alışveriş politikaları gözden geçirilmelidir. 
- Katılımcıların internet üzerinden alışveriş yapmalarının temel sebepleri; rahatlık-kolaylık, bol seçenek ve fiyat avantaj1 olduğundan, internet üzerinden alışveriş hacimleri az olan işletmeler, özellikle bu faktörler açısından kendi analizlerini yapabilmelidir.

- İnternet üzerinden alışveriş yapmayan kişilerin alışveriş yapmama sebepleri analiz edilmeli, bu konuda gerekli stratejiler geliştirilmelidir.

- İnternet üzerinden alışveriş deneyimi ile ilgili olarak müşterilerin gerek alışveriş öncesinde gerek alışveriş esnasında ve gerekse alışveriş sonrasında ulaşabilecekleri etkili bir müşteri hizmetleri olmalıdır.

Yapılan araştırmada algılanan e-hizmet kalitesi, müşteri tatmini ve müşteri sadakati arasındaki ilişkiler dikkate alınmıştır. Bundan sonra yapılacak çalışmalarda, algılanan değer ya da e-mağaza imajı gibi literatüre katkısı olan başka değişkenler de modele eklenerek araştırma genişletilebilir.

$\mathrm{Bu}$ çalışma, internetten alı̧̧veriş yapan Adıyaman Üniversitesi öğrencileri üzerinde uygulanmıştır. Yine benzer şekilde farklı meslek grupları, farklı elektronik pazar grupları ve günümüzde daha çok ön planda olan ve teknolojiyi daha yoğun kullanan $\mathrm{Z}$ kuşağı gibi farklı örneklem grupları üzerinde de benzer çalışmalar yapılabilir.

\section{KAYNAKÇA}

Aaker, D. and Jacobson, R. (1994, 05). The financial information content of perceived quality. Journal of Marketing Research, 31(2), 191-201.

Aslan, R., \& Özbeyaz, A. (2019). Satın alma sürecinde marka bağımlılığı üzeine bir araştırma: Adıyaman Üniversitesi örneği. İnsan ve Toplum Bilimleri Araştırmaları Dergisi, 8(3), 1968-1990.

Bayram, A. (2015). Seyahat acentelerinin e-hizmet uygulamalarının kalitesinin müşteri memnuniyeti ve müşteri sadakatine etkisi: Ankara örneği. [Yayınlanmamış doktora tezi]. Gazi Üniversitesi,

Baytekin, E. P. (2005). Toplam kalite hedefinde müşteri memnuniyetinden müşteri sadakatine. Ege Üniversitesi İletişim Fakültesi Yeni Düşünceler EDergisi(1), 41-52.

Bayuk, M. N. ve Küçük, F. (2007). Müşteri tatmini ve müşteri sadakati ilişkisi. Marmara Üniversitesi İ̈BF Dergisi, 22(1), 285-292. 
Bilgilier, H. A. (2019). Y kuşağının internetten alışverişe yönelik tutumlarn: nicel bir araştırma. Erciyes Illetişim Dergisi, 6(1), 487-512.

Bozbay, Z., Yaman, Y. ve Özkan, E. (2016). İnternet perakendeciliğinde hizmet kalitesinin müşteri memnuniyeti üzerindeki rolü: hazır giyim ve kitap sektörü üzerine karşılaştırmalı bir araştırma. Ulaştırma ve Lojistik Dergisi, l(1), 20-40.

Campanella, J. (1999). Principles of quality cost: Principles, implementation and use. ASQ Quality Press.

Cristobal, E., Flavian, C. and Guinaliu, M. (2007). Perceived e-service quality measurement validation and effects on. Managing Service Quality, 17(3), 317-340.

Crosby, P. B. (1979). Qualty is free: the art of making qualty certain. Penguin Books.

Çatı, K. ve Koçoğlu, C. M. (2008). Müşteri sadakati ile müşteri tatmini arasındaki ilişkiyi belirlemeye yönelik bir araştırma. Selçuk Üniversitesi Sosyal Bilimler Enstitüsü Dergisi(19), 167-188.

Çelik, M. (2012). Müşteri memnuniyeti ve hizmet kalitesi üzerine adiyaman üniversitesi yemekhanesi'nde bir uygulama. Adlyaman Üniversitesi Sosyal Bilimler Enstitüsü Dergisi, 5(10), 29-54.

Çiftçi, A. G. (2006). Hizmet kalitesi ve bankactlık sektöründe hizmet kalitesi ölçümüne yönelik bir uygulama. [Yayınlanmamış yüksek lisans tezi]. Dokuz Eylül Üniversitesi,

Çınar, A. T. (2007). İsletmelerde müşteri hizmeti ve müşteri memnuniyeti ile farklı bankalar ve bölgeler için müşteri memnuniyetini belirlemeye yönelik uygulama. [Yayınlanmamış yüksek lisans tezi]. Adnan Menderes Üniversitesi.

Davids, M. (2007). Going beyond customer satisfaction to customer loyalty. Newcomb Maketing Solutions, Debt. May/Jun. 19-22.

Değermen, H. A. (2006). Hizmet ürünlerinde kalite, müşteri tatmini ve sadakati (hizmet kalitesi ile müşteri sadakatinin sağlanması ve gsm sektöründe bir uygulama, Türkmen Kitabevi.

Demirkan, G. (2015). Lojistik işletmelerinde müşteri iliş̧kileri yönetiminde algılanan hizmet kalitesinin marka sadakati üzerine etkisi ve bir araştırma. [Yayınlanmamış yüksek lisans tezi]. Deniz Harp Okulu. 
Enginkaya, E. (2006). Elektronik perakendecilik ve elektronik alı̧̧veriş. Ege Akademik Bakış: Ekonomi, İşletme, Uluslararası İlişsiler ve Siyaset Bilimi Dergisi, 6(1), 10-16.

Erdil, T. S., ve Uzun, Y. (2010). Marka olmak (Cilt 2.). Beta Yayınc1lık.

Franzen, G. (2002). Reklamın marka değerine etkisi (Cilt 2.). (F. Yalım, Çev.) MediaCat Kitapları.

Grewal, D., Monroe, K. B. and Krishnan, R. (1998). The effects of pricecomparison advertising on buyer' perceptions of acquisition value, transaction value, and behavioral intentions. Journal of Marketing, 62(2), 46-59.

Grönroos, C., Heinonen, F., Isoniemi, K. and Lindholm, M. (2000). The netoffer model: a case example from the virtual marketspace. Management Decision, 38(4), 243-252.

Gümül, F. (2015). Tüketicilerin internetten alışveriş davranışını etkileyen faktörler:Yüzüncü Yll Üniversitesi öğretim elemanlar üzerine bir uygulama. [Yayınlanmamış yükssek lisans tezi].Yüzüncü Y1l Üniversitesi.

İçli, G. E. (2002). İnternetten alışverişte tüketicinin algıladiğı risk ile riski azaltıcı stratejiler ve bir uygulama. [Yayınlanmamış doktora tezi]. Marmara Üniversitesi,

İlter, B. (2009). E-perakendecilikte e-hizmet kalitesi, müşteri memnuniyeti ve müşteri sadakati ilişkisi: işletme fakültesi öğrencileri üzerine bir uygulama. Dokuz Eylül Eniversitesi, İşletme Fakültesi Dergisi, 10(1), 97-117.

İlter, B. (2009). E-Perakendecilikte e-hizmet kalitesi, müşteri memnuniyeti ve müşteri sadakati ilişkisi: işletme fakültesi öğrencileri üzerine bir uygulama. Işsletme Fakültesi Dergisi, 10(1), 97-117.

Kalayc1, Ş. (Dü.). (2005). SPSS uygulamalı çok değişkenli istatistik teknikleri. Asil Yayın Dağıtım.

Kipman, M. (2013). Online (çevrimiçi) alışverişs sitelerinde e-hizmet kalitesi ve e-hizmet telafi kalitesi'nin elektronik sadakat üzerine etkileri. [Yayınlanmamış doktora tezi].Marmara Üniversitesi.

Kırcova, İ. (2005). Internet'te pazarlama. Beta Yayınları. 
Kırkbir, F. (2007). Türkiye'de termal turizm pazarlamasında müşteri sadakatine yönelik yapısal bir model önerisi. [Yayınlanmamış doktora tezi]. Karadeniz Teknik Üniversitesi.

Kotler, P. (2019). A'dan Z'ye pazarlama. (A. K. Bakkal, Çev.) MediaCat Kitapları.

Kuyucu, Ş. (2021). Internet Allşverişlerinde Algllanan E-Hizmet Kalitesi, Müşteri Tatmini ve Müşteri Sadakati Illişkisinin Incelenmesi: Adıyaman Üniversitesi Öğrencileri Üzerine Bir Uygulama", [Yayınlanmamış yüksek lisans tezi].Adıyaman Üniversitesi.

Modahl, M. (2001). Now or never: how companies must change today to win the battle for internet consumers. Harper Paperbacks.

Mohamed, H., Elias, N. F. and Arridha, R. R. (2015). Measuring perceived eservice quality. The fourth Asian conference on information systems (ACIS 2015), (s. 1-5).

Naktiyok, A. ve Küçük, O. (2003). İşgören (iç müşteri) ve müşteri (dış müşteri) tatmini, işgören tatmininin müşteri tatmini üzerine etkileri: ampirik bir değerlendirme. Atatürk Üniversitesi İktisadi ve İdari Bilimler Dergisi, 17(1-2), 225-241.

OECD. (2000). E-commerce: impacts and policy challenges. 17.03.2020 tarihinde oecd.org: http://www.oecd.org/economy/outlook/2087433.pdf adresinden alındı

Oyman, M. (2002). Müşteri sadakati sağlamada sadakat programlarının önemi. Kurgu Dergisi(19), 169-185.

Özer, L. Ş. (1999). Müşteri tatminine yönelik literatürdeki kuramsal tartışmalar. Hacettepe Üniversitesi İktisadi ve İdari Bilimler Fakültesi Dergisi, 17(2), 159-180.

Parasuraman, A. P., Zeithaml, V. A. and Malhotra, A. (2005). E-S-Qual: A multiple-item scale for assessing electronic service quality. Journal of Service Research, 7(3), 213-233.

Şale, İ. (2001). Adım adım toplam kalite uygulamaları (Cilt 1). Seçkin Yayıncılık.

Şenel, B., Şenel, M. ve Gümüştekin, G. E. (2012). E-hizmet kalitesine göre sanal alışveriş sitelerinin değerlendirilmesi. Dumlupınar Üniversitesi Sosyal Bilimler Dergisi(33), 85-100. 


\section{A.Yıldız-S.Kuyucu Internet Alısverislerinde Algılanan E-Hizmet...}

Tekin, M. (2012). Toplam kalite yönetimi (cilt 7). Günay Ofset.

Tekin, M. ve Zerenler, M. (2012). Pazarlama (cilt 1). Günay Ofset.

Türk, Z. (2009). Denetim firmalarının sunduğu hizmet kalitesi, müşteri tatmini ve sadakati: servperf ölçeği. Çukurova Üniversitesi Sosyal Bilimler Enstitüsü Dergisi, 18(1), 399-416.

Ünal, S. (2010). İnternet üzerinde izinli pazarlama yaklaşımı. Öneri Dergisi, 9(34), 155-162.

kobitek.com: https://kobitek.com/kalitenin-pazarlama-boyutu adresinden 25.03.2020 tarihinde alınd1

Wikipedia.org:

https://tr.wikipedia.org/wiki/\%C3\%87evrimi\%C3\%A7i_al\%C4\%B1\%C5

$\% 9$ Fveri $\% \mathrm{C} 5 \% 9 \mathrm{~F}$ adresinden alınd 1

TDK:

https://sozluk.gov.tr/?kelime=yakla\%C5\%9F\%C4\%B1k\%20de\%C4\%9F

er adresinden 21.04.2020 tarihinde alınd 